Discussion Paper No. 08-093

\title{
Is Temporary Employment a Stepping Stone for Unemployed School Leavers?
}

Christian Göbel and Elsy Verhofstadt

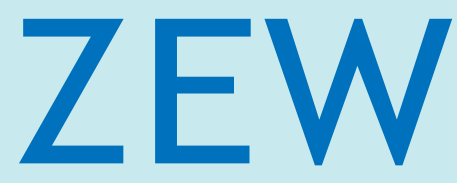

Zentrum für Europäische Wirtschaftsforschung $\mathrm{GmbH}$

Centre for European

Economic Research 
Discussion Paper No. 08-093

\section{Is Temporary Employment a Stepping Stone for Unemployed School Leavers?}

Christian Göbel and Elsy Verhofstadt

Download this ZEW Discussion Paper from our ftp server:

ftp://ftp.zew.de/pub/zew-docs/dp/dp08093.pdf

Die Discussion Papers dienen einer möglichst schnellen Verbreitung von neueren Forschungsarbeiten des ZEW. Die Beiträge liegen in alleiniger Verantwortung der Autoren und stellen nicht notwendigerweise die Meinung des ZEW dar.

Discussion Papers are intended to make results of ZEW research promptly available to other economists in order to encourage discussion and suggestions for revisions. The authors are solely responsible for the contents which do not necessarily represent the opinion of the ZEW. 


\section{Non technical summary}

Many school-leavers enter the labour market via temporary employment. As employers could exploit the weak bargaining position of job starters, fixed-term contracts at the beginning of the labour market career are often criticized. However, temporary employment at this stage may as well act as a stepping stone into permanent employment. This is the case if it is easier to transit from temporary employment into permanent employment than from school to permanent employment.

The paper investigates for a sample of Flemish school leavers whether a temporary employment spell at the start of the career has a positive or negative impact on the transition rate into permanent employment. Our analytical benchmark is the case of a direct transition from unemployment to permanent employment. Do individuals who start with fixed-term employment reach permanent employment more or less quickly?

The fundamental problem in this type of study is that school-leavers who enter temporary employment are probably not a random group. They are likely to differ in their characteristics from school-leavers who do not enter temporary employment. If this is the case, simple comparison of transition rates for the two groups would not only capture the impact of temporary employment, but also the effect of the different characteristics.

In order to control for selective participation in temporary employment, we use a large set of explanatory variables especially collected to study school-leavers. Furthermore we apply advanced statistical methods to test for the presence of selection in unobserved characteristics. Based on our statistical test, we conclude that given our data, there is no support for selection in unobserved characteristics.

Simulation exercises give insight into temporary employment effects changing over time elapsed since school-leaving. In the short run temporary employment delays transition to permanent employment. But in the long run temporary employment acts as stepping stone and reduces the time required before reaching permanent employment. From this perspective fixed-term contracts at career entry appear as beneficial. 


\section{Das Wichtigste in Kürze}

Schulabgänger beginnen das Arbeitsleben häufig mit einem befristeten Arbeitsverhältnis. Diese Befristungen werden häufig kritisiert. Arbeitgeber könnten hiermit ihre relativ starke Verhandlungsposition gegenüber den Berufseinsteigern ausnutzen. Andererseits könnten Befristungen auch die Funktion eines Sprungbretts zu unbefristeten Arbeitsverhältnissen übernehmen. Dies wäre der Fall, wenn Berufseinsteiger mit befristetem Arbeitsverhältnis schneller einen unbefristeten Vertrag erhielten als Absolventen, die nicht mit einem befristeten Vertrag starten.

Diese Studie untersucht anhand einer Stichprobe von Schulabgängern aus Flandern (Belgien), ob ein befristeter Vertrag am Beginn des Erwerbslebens die Übergangsraten in unbefristete Stellen erhöht oder vermindert. Die analytische Referenzmarke ist der direkte Übergang aus der Arbeitslosigkeit in unbefristete Beschäftigung.

Das zentrale Problem der Analyse ist, dass sich die arbeitmarktrelevanten Charakteristika von Absolventen, die befristete Beschäftigung aufnehmen, von denen der Absolventen, die dies nicht tun, vermutlich systematisch unterscheiden. Handelt es sich um selektierte Gruppen, misst der einfache Vergleich der Übergangsraten nicht nur die Wirkung der befristeten Beschäftigung, sondern auch den Effekt der Selektion.

Um selektionsbedingte Verzerrungen auszuschalten, nutzen wir eine sehr große Zahl von Kontrollvariablen, die eigens für die Untersuchung des Übergangs vom Schul- in das Erwerbsleben gesammelt wurden. Dass in den Daten Selektion in unbeobachtbaren Charakteristika vorliegt, kann anhand moderner statistischer Testmethoden ausgeschlossen werden.

Anhand von Simulationen lässt sich die unterschiedliche Wirkung befristeter Beschäftigung in Abhängigkeit von der Zeit herausarbeiten. Unsere Ergebnisse sprechen dafür, dass Befristungen kurzfristig den Übergang in permanente Beschäftigung verzögern können. Langfristig erweist sich befristete Beschäftigungsverhältnisse aber als Sprungbrett für eine unbefristete Stelle. 


\title{
Is temporary employment a stepping stone
}

\section{for unemployed school leavers?}

\author{
Christian Göbel ${ }^{1}$ and Elsy Verhofstadt ${ }^{2}$
}

\begin{abstract}
Many school-leavers enter the labour market via temporary employment. In this paper we investigate the impact of a temporary employment spell at the start of the career on the transition rate into permanent employment. We compare the case of temporary employment to the hypothetical case of a direct transition from unemployment to permanent employment. In order to control for selective participation in temporary employment we include a large set of explanatory variables which have been especially collected to study school-leavers. We apply the AIC-information criterion to select the appropriate specification for unobserved heterogeneity. Based on the information criteria we conclude that given our data, there is no support for a model with selection in unobserved characteristics. Simulation exercises provide insights into the development of the effect of temporary employment over time. For a sample of unemployed Flemish school-leavers we find that in the short run temporary employment delays the school leaver's transition to permanent employment. However, in the long run temporary employment acts as a stepping stone and decreases the duration until permanent employment.
\end{abstract}

JEL : $\quad$ J41, J64, J08

Keywords : temporary employment, school leavers, labour market policy

\footnotetext{
${ }^{1}$ ZEW, Centre for European Economic Research, Mannheim, Germany

${ }^{2}$ HABE, University College Ghent - Sherppa, Ghent University

Correspondence to: Elsy Verhofstadt, Ghent University, Tweekerkenstraat 2, 9000 Ghent, Belgium e-mail: Elsy.Verhofstadt@UGent.be.

The authors acknowledge support from the Flemish Ministries of Science and Technology and Education (PBO 1997 and 1998) and the Interuniversity Attraction Poles Program - Belgian Science Policy [Contract no. P5/21]. We thank Thomas Zwick, Melanie Arntz, Bart Cock, Eddy Omey, Dirk Van de Gaer, Hans De Witte, Gerdie Everaert, Walter Van Trier, Peter Vlerick, Henriette Maassen Van den Brink and the seminar participants at ZEW and Sherppa for helpful comments. We thank conference participants in London, Oslo, Ghent, Louvain-La-Neuve and Graz for the discussions and comments.
} 


\section{Introduction}

In this paper we provide a study on the transition from school to working life. More precisely, we study the effect of a transition to temporary employment on the transition rate into permanent employment for unemployed school-leavers. In the following, temporary employment is defined as employment with a fixed-term employment contract. In contrast, permanent employment refers to contracts where the end of the employment relationship is not fixed in advance. School-leavers are those who leave the educational system either after primary, secondary or tertiary education. We try to answer the question whether temporary employment is a stepping stone to permanent employment for unemployed school-leavers. Using a Flemish sample, we contrast the case of temporary employment to the hypothetical case of a direct transition from unemployment to permanent employment. In order to control for selective participation in temporary employment we include a large set of explanatory variables. We apply the AIC-information criterion to select the appropriate specification for the unobserved heterogeneity. Based on the information criteria we conclude that given our data, there is no support for a model with selection in unobserved characteristics. We conduct simulation exercises in order to provide insights into the dynamic development of the effect of temporary work for unemployed school-leavers. We find that in the long run temporary employment acts as a stepping stone for unemployed school-leavers and decreases the duration until permanent employment.

\section{Youth labour market problems}

One of the most striking labour market developments of recent decades has been the declining economic status of young workers (Blanchflower and Freeman, 2000). In most Western European countries this is reflected in high unemployment rates. Table 1 illustrates that the unemployment-rate is much higher for young workers than for the rest of the active population. In 2005 the unemployment rate of people younger than 25 was more than two times higher than the unemployment rate for the over 25 years' old, in most European countries. In Flanders, the region we focus on throughout this paper, the unemployment rate has even been three times higher for young people than for the older ones.

Table 1: Unemployment in Europe and Flanders (2005)

\begin{tabular}{lcc}
\hline (\%) & \multicolumn{2}{c}{2005} \\
& EU-15 & Flanders \\
\hline -25 year & 16.9 & 14.2 \\
+25 year & 7.1 & 4.5 \\
(Eurostat, LFS adjusted series) &
\end{tabular}

The potential implications of the described phenomenon for the young workers and for the society as a whole are important. High unemployment rates reflect a large underutilisation of human resources. Furthermore, unemployment at young age might have a permanent influence on the future labour 
market prospects of the workers. The transition period from school to work marks an important step in life and substantially influences the subsequent labour market performance and well-being of the school-leavers (SONAR, 2001). ${ }^{3}$

Besides the fact that young workers have problems to enter employment, they enter the labour market often through temporary employment (Ryan, 2001). In Europe, about $40 \%$ of the workers, younger than 25 , are employed with a temporary contract (32\% in Belgium). For the older working population (25 years and older) only $11 \%$ of the employees are temporary ones (6.5\% in Belgium) (Eurostat, EU-15, LFS series, 2005).

Research on the workers motives behind the acceptance of temporary employment has shown that most workers in temporary employment would prefer a permanent contract (e.g. De Witte et al., 2001 and Guest, 2004). Moreover, this branch of literature highlights the fact that workers accept temporary employment contracts because they hope to enhance their chances of becoming permanently employed in the long term (Declerck et al., 2006).

\section{Contribution to literature}

Both phenomena, the high unemployment rate and the high incidence of temporary employment for young workers, point to the importance of the transition from school to working life. In depth knowledge of the dynamics of the transition from school to work is crucial in order to understand and tackle the youth labour market problems. It is one contribution of this paper that we investigate the role of temporary employment for unemployed school-leavers.

Despite the relevance of this subject, the existing literature on school-leavers has left out either the aspect of temporary employment or the aspect of unemployment. Among the first type of study, that investigates the transition from unemployment to work without considering temporary employment are papers by Bradley and Taylor (1991), Bratberg and Nilsen (2000), Nielsen et al. (2003) and Vanoverberghe et al. (2008) - respectively for the UK, Norway, Denmark and Flanders.

The other branch of the literature on school leavers investigates the role of temporary employment, without considering the issue of unemployment: For example McGinnity et al. (2005) found no difference in the probability of future employment irrespective of whether or not one starts in temporary or permanent employment, for Germany. Scherer (2004) considers the occupational status of future employment. She founds reduced chances for access to "higher" positions for starters in temporary employment for Germany and higher unemployment risks for starters in temporary employment in Italy.

Remarkably, none of the existing studies on school-leavers investigates the role of temporary employment for the transition from unemployment to work. We want to fill the gap by answering the question whether temporary employment helps unemployed school-leavers to integrate into the

\footnotetext{
${ }^{3}$ In a paper by Nordström Skans (2004) on the Swedish youth labour market, it has been argued that postgraduation unemployment has a long-lasting negative effect on the labour market performance.
} 
labour market. Furthermore, our paper is the first one that provides insights on the dynamic development of the effect of temporary employment for school-leavers.

We investigate if temporary employment is a stepping stone towards permanent employment or not. To answer this question we use duration models that are closely related to Abbring and van den Berg (2003) in the sense that we use their framework to test for the presence of selection in unobserved heterogeneity. We apply a multi-state grouped duration model for our empirical investigation. We model the transition from unemployment to temporary employment, from temporary employment to permanent employment and from unemployment directly to permanent employment. The transition rates are specified in a flexible way and are allowed to depend on observed and unobserved characteristics of the school-leavers as well as on the elapsed time spent in the respective labour market state. In order to derive estimates of the causal effect of temporary employment over time, we apply simulation methods. We estimate the different transitions for unemployed school-leavers using survey data for Flanders, a region that covers the Northern part of Belgium. These Flemish data have been especially collected to investigate the entry into the labour market for school-leavers and contain a large set of variables. Many of these variables are not available in other surveys or in administrative data sets. These data allow us to construct the labour market trajectory on a monthly basis. The database is exceptionally rich and contains a whole range of explanatory variables that are likely to have explanatory power for the transition from school into the labour market. For example, the dataset contains information on parents' education, migration background, membership in clubs, financial independence, internships, the presence of a driving license, regional unemployment, the pollster's impression of the respondent and so forth.

We provide a causal evaluation of the effect of temporary employment on the time it takes to find a permanent job. For this purpose, we contrast the duration until entering a permanent job when taking a temporary job to the counterfactual duration that it would take for a direct transition from unemployment to permanent employment. This differs from the majority of the existing literature concerning temporary employment. Most papers consider the probability of getting a temporary or permanent contract ${ }^{4}$, the subsequent labour market outcomes of temporary workers ${ }^{5}$, or estimate the duration in temporary employment before finding a permanent job. ${ }^{6}$ This last category of papers starts from a temporary job as initial state and computes the duration until a permanent one, whereas we consider unemployment after leaving school as the initial state. Besides Booth et all. (2002), D'Addio and Rosholm (2005) and Guëll and Petrongolo (2007), all others only discuss the determinants and possible explanations for the duration to a permanent job. Gagliarduccis (2005) focus is on the effect of repeated temporary contracts on the probability of finding a permanent job.

\footnotetext{
${ }^{4}$ E.g. Amuedo-Dorantes (2000), Morris \& Vekker (2001), Caparros Ruiz \& Navarra Gomez (2003), Giesecke \& Gross, (2003) and Kahn (2005).

${ }^{5}$ E.g. Korpi \& Levin (2001), Booth et all. (2002), Giesecke \& Gross, (2003), Steijn \& Need (2003), Michaud \& Roger (2003), McGinnity et al.(2004), Scherer (2004), Casquet and Cunyat (2004).

${ }^{6}$ E.g.. Booth et all. (2002), D’Addio \& Rosholm (2005), Gagliarducci (2005) and Guëll and Petrongolo (2007).
} 
He distinguishes transitions from a temporary job to a permanent one with transitions from repeated temporary jobs to a permanent one. Different from his approach, we compare the duration to permanent employment (for individuals taking a temporary employment) with the counterfactual situation of staying unemployed. In addition, our paper provides the detailed time-path for the development of the effect over time.

Our type of study has received little attention. Research of this kind for Germany (Hagen, 2003), the Netherlands (Zijl et al., 2004) and Italy (Ichino et al., 2005) has indicated that temporary work accelerates the transition to permanent work in these countries; however, non of these studies focuses on school-leavers.

Two different methods have been used in the literature to answer our question: propensity score matching and duration analysis. Hagen (2003) and Ichino et al. (2005) use the first method, which relies on the presence of all relevant characteristics in the used data. ${ }^{7}$ As a result of this requirement, applying matching methods for the analysis of school-leavers would be troublesome in many cases, since most available data bases suffer from a lack a comprehensive set of explanatory variables. Furthermore, even in the presence of big data-sets it seems to be advisable to test if unobserved characteristics affect both the probability to get a temporary contract and the probability of getting a permanent contract. Duration models, conditional on assumptions (discussed in section 5), provide the means to test for selection in unobserved characteristics.

To summarize our contribution, this is the first paper that investigates the role of temporary employment on unemployed school-leavers. This paper provides details on the dynamic development of the effect, offers an empirical analysis based on a convincing data base for the investigation of the entry into the labour market and contains a formal check for the existence of remaining selection in unobserved characteristics.

The remaining of this paper is structured as follows. Section 2 provides some theoretical consideration. Afterwards, section 3 gives background information on the situation and legislation concerning school-leavers and temporary employment in Flanders. Section 4 provides details about the used data and the considered sample. In section 5 we explain the econometric model and in section 6 we provide the results. Section 7 concludes.

\section{Theoretical considerations}

Economic theory provides arguments that either support or reject the hypothesis that temporary employment is a stepping stone for unemployed school-leavers.

The human capital of school-leavers is likely to shrink in unemployment periods. This is in line with human capital theory assuming that human capital is depreciated when staying unemployed (Becker,

\footnotetext{
${ }^{7}$ See Hagen (2003) or Ichino et al. (2005) for more details about the propensity score matching approach.
} 
1986). Temporary employment can be a way to maintain or increase the stock of human capital through work experience for school-leavers.

Another argument that supports the view that temporary employment is a stepping stone builds on the importance of professional networks. When young people leave school, their professional networks tend to be small or non-existing. Taking a temporary job is likely to enlarge the network of young workers and thus offers more opportunities to get a permanent job.

For employers it is not always obvious whether the school-leavers are the persons their companies need. Therefore they might use temporary contracts as a screening device. The employer can hire the employee on a temporary basis in order to learn something about the actual productivity of the worker and keep only productive workers permanently. Besides the screening theory (Stiglitz, 1975), also signalling theory (Spence, 1973) offers an argument in favour of the stepping stone effect of temporary employment for unemployed school-leavers. By working in a temporary job they can signal to future employers both their willingness and their ability to work. Since it is not possible to infer the productivity of unemployed school-leavers from their past labour market trajectory, this argument can be expected to have more explanatory power in the case of school-leavers than in the case of experienced workers.

Even though the mentioned arguments are in favour of temporary employment, there are also a couple of theoretical arguments that suggest that temporary employment may prevent a fast integration into permanent employment. In the dual labour market theory, temporary employment is seen as employment in the bad market segment. According to this hypothesis, the labour market consists of two tiers: the primary segment with "good jobs" and the secondary, inferior labour market segment with "bad jobs". (Piore, 1970). The "confinement" proposition of the dual labour market theory says that there is little if any mobility between the primary and secondary sector and that disadvantaged workers in secondary segments are trapped in bad jobs. As a consequence schoolleavers who accept a temporary employment would remain in temporary employment.

A possible explanation for the limited mobility between both segments is negative feedback effects: due to working in secondary jobs, people acquire bad work habits and become unsuited to work in the primary sector (Tauban and Wachter, 1986). Also, signalling could provide an explanation for the low mobility between the two labour market segments. If temporary employment provides a bad signal to potential employers, e.g. since the worker didn't succeed to get a "good, permanent job", then a worker in temporary employment could be trapped. However, for young workers temporary employment is less likely to play an important role as a bad signal, since their labour market history is shorter and thus less informative. ${ }^{8}$

To sum up, economic theory provides a couple of arguments on how temporary employment affects the transition into the labour market. However, the direction of the total effect remains unclear and it

\footnotetext{
${ }^{8}$ In line with the dual labour market theory, empirical research confirms that, compared to permanent workers, temporary jobs in Flanders are associated with bad job characteristics; for example lower wages (Sels et al, 2002) and a lower training probability (Forrier et al., 2003; Verhaest et al., 2006). There are comparable results for other European countries (e.g. Booth et al., 2002).
} 
is an empirical question in which way temporary employment affects the integration of school-leavers into the labour market.

\section{The Flemish context}

\section{Flemish school-leavers}

In Flanders there is compulsory education until the age of eighteen. From the age of fifteen or sixteen only part-time schooling is compulsory. Student jobs during vocational training are considered as being part of the educational career; as a consequence we do not consider these jobs as the first job for school-leavers. In Belgium, there is no obligatory military service and schoolleavers enter the labour market directly after the end of schooling.

Different from other countries, in Belgium school-leavers can claim unemployment benefits. Roughly speaking these unemployment benefits provide a flat payment scheme that is mainly a function of the family status and that does not expire. The level of the benefits is relatively low and just above social benefits. Before an unemployed school-leaver is entitled to full unemployment benefits, there is the so-called waiting period. This period starts with the registration at the employment office after the end of the last school year. During this period (233 days for school-leavers between 18 and 26 year) the unemployed school-leaver only gets a waiting period benefit, which is lower than the regular unemployment benefits. The waiting period runs during working days. Therefore, school-leavers have an incentive to register at the employment office after leaving school, even if they have already an employment contract. This gives them the advantage to claim unemployment benefits earlier in the event of a subsequent unemployment spell.

Similar to other European welfare states, Flanders applies active labour market policies to integrate unemployed school-leavers into the labour market. The most important labour market policy for unemployed Flemish school-leavers is the "First Job Agreement". This can be a temporary contract, a permanent contract or an active labour market program ${ }^{9}$. For larger companies (more than 50 employees) there is an obligation to achieve a youth quota of at least $3 \%$ of their work force. In exchange, under certain conditions, the employers are entitled to reductions in the social security contributions. The reductions can also be bigger, and combined sometimes with other programs when the employer hires poorly qualified young people or long-term unemployed. ${ }^{10}$

\section{Employment contracts in Flanders}

\footnotetext{
${ }^{9}$ We come back to the treatment of active labour market programs in section 5 .

${ }^{10}$ The amount of the reduction differs a lot. In 2004 the system was simplified to a maximum reduction of 1.000 $€$ every quarter during the first 8 quarters and $400 €$ for all the following quarters until the maximum age of 26.
} 
Labour regulation distinguishes two types of employment contracts: with or without time stipulation. The latter are permanent contracts. ${ }^{11}$ Employment contracts with a time stipulation are what we call 'temporary employment'.

As in many European countries also in Belgium, the application of temporary employment contracts is limited by law. A limited number of consecutive temporary employment contracts, between the same employee and employer, are possible for a maximum of 3 years. Other employment contracts are considered as being permanent, unless they are justified through the temporary nature of the job or other legal reasons.

A temporary contract has a starting date and an ending date and ends automatically on the date agreed. This means that there is no dismissal procedure involved. An option to terminate the contract before the final date has to be an explicit part of the contract. A permanent labour contract can be ended by one of the parties whereby the legal terms of notice need to be respected (depending on the duration of the contract). The rules are different for employers and employees. The employee has the right to end the contract without a procedure, but he or she has to respect the legal and agreed determination period, which usually is a one-month notice minimum.

Compared with other European countries the difference in employment protection legislation between temporary and permanent contracts is more balanced in Flanders (OECD, 2004). Overall in Europe, strict regulation for temporary contracts tends to go together with strict regulation for permanent contracts. For Flanders one can notice that this balance is to a little extent in favour of more regulation on temporary employment and less protection of permanent workers (OECD, 2004). During the last decade there is a growing percentage of temporary employment in Flanders despite the absence of major changes in the employment protection legislation.

\section{Data on Flemish school-leavers}

\section{Survey data}

We use a survey database for Flanders (SONAR), collected to study the transition from education to the labour market. Therefore the database is exceptionally rich on labour market information for school-leavers in their first working experiences. It contains monthly information on the labour market status from the moment one leaves school until the moment of the last interview as well as a whole range of socio economic variables. ${ }^{12}$ As a consequence, the dataset contains information, which is often not available in other samples (e.g. information on internships, student jobs, driving

\footnotetext{
${ }^{11}$ Permanent employment contracts can specify a probationary period, during which the worker can be fired if unsatisfactory without severance payment. Employment under probation is thus (possibly) part of a permanent contract and not considered as a temporary contract.

12 Since the data set contains monthly information for some key variables, we have the contract type for every job. This is an advantage compared to Zijl et al. (2004), who use a similar method (cfr. supra), because they have to infer the contract type of jobs between interview times from other variables.
} 
license and club membership). In these data, employment experience is registered as soon as it exceeds one hour per week, for a job-duration of at least one month.

The data collection has been accomplished in a longitudinal follow-up design. This study will use two cohorts of young adults, born in 1976 or 1978. The adults in our sample were questioned a first time when they were 23 years old and a second time when they were 26 years old. ${ }^{13}$ The samples were randomly selected and trained interviewers performed the oral interviews at the home of the interviewees. The dataset is thus based on self-reported information of the respondents. The face to face interviews also allowed collecting information on the impression that the interviewer received from the school-leaver.

The SONAR group investigated the representativity of the database (SONAR, 2000). With respect to gender and family formation the sample is roughly representative. In line with responses in other surveys, lower educated, unemployed and respondents from lower social classes are slightly underrepresented. Comparing the sample with respect to additional characteristics is close to impossible because of a lack of comparable or representative data.

\section{Sample}

Since we are interested in a causal analysis for unemployed school-leavers special care has to be taken when selecting the sample. There are two related issues that have to be considered. The first concerns unreliable information on the unemployment-status at the end of schooling and the second issue concerns the danger that anticipation of future employment could flaw the causal analysis.

First some words about unreliable information on the unemployment status. In Belgium, as in most other countries, schooling typically ends by the start of the summer. For example, in our data, about $90 \%$ of the school-leavers end school in June. However the first employment-spells for schoolleavers typically start only after a break of 2-3 month. In fact, even though many school-leavers have already an employment contract at the end of school, most of their jobs do not start during the summer months, e.g. because employers are reluctant since many of their employees are in holidays anyway and new arriving school-leavers typically need some guidance when they start working. Also school-leavers might think that they deserve summer-holidays after the final exams. As a result, many of the school-leavers report a short period of inactivity or unemployment directly at the end of schooling - even though most of them already have an employment contract at the end of schooling. Actually, for institutional reasons the school-leavers might register as unemployed and report this in the questionnaire, even though they are not actively looking for a job in this period. To summarize, the information on unemployment during the months directly after the end of schooling are likely to be not reliable. ${ }^{14}$

The second issue is about the possible consequences of the described phenomena for a causal analysis in longitudinal studies. We argued above that it is likely that directly after leaving school, a

\footnotetext{
${ }^{13}$ The response rate for the follow up interviews was about $70 \%$. .

${ }^{14}$ These arguments apply to most westernized countries and have been largely ignored in the existing literature.
} 
part of the reported "unemployed" school-leavers are actually waiting for their first job to start. Here, the potential problem comes from the fact that waiting or unemployment have different behavioural implications on search behaviour and consequently on labour market outcomes. ${ }^{15}$ Technically speaking the problem arises since these behavioural consequences are conditional on future outcomes of the realisation of the labour market transition. This is a form of endogeneity, which is known to flaw estimation results. The described problem is likely to be present for a considerable part of school leavers during the first months after leaving school.

In order to avoid the described problems and to make sure that the school-leavers are actually unemployed, we restrict the sample to school-leavers who are unemployed in the third month after leaving school. ${ }^{16}$ This has the drawback that the obtained results are all conditional on this restriction. However we argue that the advantages in terms of validity of the data and the reliability of our results largely outweigh this drawback. This approach leaves us with a sample of 1542 unemployed school-leavers.

\section{Overview of the variables}

To explain the transition from unemployment to employment and in order to control for selective participation in temporary employment, one should include all relevant variables into the empirical model. In addition to variables like gender, age and nationality, which are available in virtually every data-set on workers labour market performance, there are many other variables that are likely to be important.

For example human capital theory (Becker, 1964) implies that investment into education increases productivity. In addition education and work experience could be a signal for the effort and professional ambition of school-leavers. Since productivity, effort and ambition are likely to be important for the transition into the labour market, it is important to integrate variables on the education of the young workers. The dataset contains the educational level and if the education is of the vocational type or not. Also information on apprenticeships during education and on student work during education is likely to be important to explain the transition from schooling into the labour market. This type of information should cover specific forms of work-experience, the general attitude towards the work and the motivation of the young workers.

Social capital and network theories (see, e.g. Montgomery, 1991) explain the importance of informal networks to receive (more) job offers. Respondents with a good social background and thus betterdeveloped informal networks are likely to receive more job offers. The dataset contains detailed information on the family background of the workers, such as the number of brothers and sisters but

\footnotetext{
${ }^{15}$ The empirical test of Flinn and Heckman (1983) support our view that unemployed are more actively looking for a job. Flinn and Heckman tested empirically whether the exit rate from unemployment to employment is the same as that from out of the labour force to employment, while examining observed and unobserved individual differences in explanatory variables.

${ }^{16}$ Another way to rationalize this decision is to simply consider the school-holidays at the end of the last year at school as being part of the period in education.
} 
also the nationality of the grandmother, indicating migration background and the educational level of the mother.

Information on the financial independence and financial needs are likely to be important to explain search intensity and preferences for certain types of jobs. The database contains information that is directly related to the financial situation of the school-leaver. One variable is covering financial independence of the parents. Moreover we know if the young worker lives together with his partner and the number of children he/she has.

Variables that are likely to cover personality traits are that on membership in clubs, a variable that may reveal information on social capital or social integration and the variable that contains the pollsters' impression of the respondent. The pollsters had to answer 8 questions to get insight in how they experience the respondent. Therefore, the pollsters have to score the respondents to which account they are energetic, active, calm, friendly, cheerful, open, optimistic and motivated to answer. Using factor analysis we created a single variable indicating how others perceive the respondents. We only used the items calm, friendly and open since we believe that these variables are unlikely to change over time. Variables like optimistic or motivated could also be the outcome of the labour market history. Therefore, we exclude these variables to avoid endogeneity bias.

The welfare typology of the area the young worker lives in is another variable that may cover otherwise unobserved characteristics, since the social network, the personal characteristics and values of people are likely to be correlated with the type of living area (rural, urban industrial or residential area).

The presence of a driving license should have an effect on the transition into the labour market since it enhances the mobility of the workers. Moreover, in Europe, to acquire a driving license one needs a substantial amount of money and specific skills.

Finally, the data-set contains the regional, time-varying unemployment rates to reflect difference in the economic performance of the different regions.

\section{Differences in descriptive statistics}

In the following sub-section we focus only on some key differences and similarities between unemployed school-leavers who have a transition from unemployment to temporary employment and unemployed school-leavers with a (direct) transition from unemployment to permanent employment. The complete table with the statistics of all explanatory variables can be found in appendix 2 .

The most remarkable difference is with respect to gender. There is a large preponderance of women over men in the subgroup of the workers with a transition to temporary employment. In the other subgroup (transition to permanent employment) men have a clear preponderance. The variables referring to ethnicity, social background of the individual and the number of siblings are very similar in both groups.

Workers with a lower tertiary degree are overrepresented, in the subgroup of temporary workers. The number of respondents with a higher secondary degree is higher in the subgroup of permanent workers. Among temporary workers the fraction of ending education in a vocational type $(6.5 \%)$ is 
lower than among permanent workers. The distribution for the welfare typology also differs significantly between both subgroups. A transition to temporary employment seems more common in urbanised areas. Among the school-leavers in residential areas the fraction of a transition to permanent employment is higher than among those with a transition to temporary employment.

\section{Econometric model}

The idea behind our approach is to consider a transition to temporary employment as a treatment that applies to unemployed school-leavers, and evaluate if this treatment accelerates the transition into permanent employment, compared to the counterfactual situation without a treatment. In different words, we investigate if the transition rates into permanent employment after entering temporary employment are higher or lower than they would have been in the hypothetical case of no entry into temporary employment. To answer this question one has to take into account that unemployed school-leavers who have a transition into temporary employment and those who have a direct transition into permanent employment may have different observed and unobserved characteristics. Without controlling for these characteristics it would be impossible to tell if the observed labour market outcomes are due to the specific characteristics or due to the effect of the transition into temporary employment. Furthermore, we estimate how these effects change over time. Figure 1 in the appendix illustrates this idea.

In our empirical model, unemployed school-leavers either have a transition to temporary employment or to permanent employment. For school-leavers who have a transition into temporary employment, we consider the subsequent duration between first entry into temporary employment and a transition into permanent employment. The duration between a transition into temporary employment and a transition into permanent employment is allowed to be composed of several temporary employment or unemployment periods. Consequently, we allow for cases where it is possible that the treated school leavers are trapped in a sequence of temporary employment and unemployment spells after their first transition into temporary employment.

The observed spells can be right censored for various reasons. If we do not observe a transition out of the respective labour market state then the ongoing spell is censored at the end of the observation period. Moreover, if a worker has a transition into an active labour market program, self-employment or full time education, then the corresponding spells are right censored at the end of the time-period just before this transition is observed. ${ }^{17}$

\footnotetext{
${ }^{17}$ Alternatively one could fully integrate these states into a transition model with an extended state-space which, however is beyond the scope of this paper. Fitting multivariate, multi-spell data with many states is computationally very demanding and is likely to provide only limited benefit for the analysis in this paper.
} 
In order to identify the causal effect of a transition into temporary employment on the duration until a transition into permanent employment we apply a model that is closely related to the "timing of events" approach (Abbring and van den Berg, 2003). Roughly speaking the "timing of events approach" is able to solve the endogeneity problem caused by selective treatment without the need of exclusion restrictions. Instead, the variation in the timing of the transition to temporary employment is exploited, in order to identify the effect on the duration of interest. ${ }^{18}$ This is achieved in a duration model, where the selection process and the transition of interest can be related via multivariate unobserved heterogeneity. However, even though the evaluation idea is inspired by the timing of events approach, given our data, it turned out that a specification with independent transitions is applicable, i.e. given our data we do not find support for selection in unobserved characteristics. With independent transitions the assumptions on the variation of the explanatory variables that are required for identification are weaker, as outlined in the next subsection.

To estimate the causal effect of temporary employment, we have to consider that the characteristics of school-leavers who have a transition to temporary employment might be systematically different from those with a direct transition to permanent employment without intermediate temporary employment. Therefore, we have to take observed and unobserved characteristics of the individuals into account. To control for selection in observed characteristics, we include a large set of explanatory variables in our duration model. These variables (cf. appendix 2) include individual characteristics, information on the socio economic background of the individuals and information about the local labour market conditions. In order to control for selection in unobserved characteristics we proceed in two steps. First we test the presence of remaining unobserved heterogeneity for each of the transition rates separately. Only if unobserved heterogeneity is present for both of the two destination states (transition into temporary employment and transitions into permanent employment) it is necessary to estimate a model with dependent unobserved characteristics between the transition rates, in a second step.

\section{Identification of the mixed proportional hazard model}

In this section we are going to discuss some key assumptions for the identification of causal effects within the empirical model. We proceed as follows, first we summarize the identification assumptions for the identification of causal effects in multivariate mixed proportional hazard models (i.e. timing of events). This discussion is useful since most of the requirements hold for our final specification. Secondly, we shortly outline in which way the identification assumptions can be relaxed in the case of independent transitions. ${ }^{19}$

\footnotetext{
${ }^{18}$ The identification of the "timing-of-events" approach relies on various assumptions (Abbring and van den Berg, 2003). Several of these assumptions are discussed in the next subsection.

${ }^{19}$ For a detailed discussion of the identification of duration models and the timing-of-events approach we refer to Van den Berg (2001) and Abbring and Van den Berg (2003).
} 
In order to be able to identify this model, it is necessary to assume independence between the vector of the unobserved heterogeneity terms and the observed characteristics. ${ }^{20}$ Furthermore, we need exogenous variation in the timing of the transitions. From the descriptive statistics it is clear that there is variation in the timing of the transitions for the different transitions. Moreover, it seems reasonable that there exists considerable randomness in the timing of the job offers for unemployed workers and it is not hard to imagine that two otherwise identical school-leavers have different unemployment durations because one of them had good and the other one bad luck. We also would like to point out that the idea of random job offer rates is widely used in economic theory, e.g. in the job-search literature (e.g. Mortensen, 1986).

Another assumption which is required for identification is the absence of anticipation of the timing of treatment. To satisfy the condition of non-anticipation one either needs that workers do not know the exact moment of a transition to temporary employment in advance or that they do not change their job search behaviour conditional on this information. As explained above, the plausibility that the "absence of anticipation" assumption is fulfilled depends also on the selected sample. For example, in a sample of all school-leavers one could expect to have some school-leavers who got a job offer already during schooling time. Since jobs for school-leavers often start within a short period after the end of schooling it is likely that some of these school-leavers have a short "unemployment" period before they start working on their first job. But the a-priori knowledge of the timing of the job-start could lead to anticipation for this group.

For a sample of unemployed school-leavers, as used in this paper, where we condition on unemployment for at least three consecutive months after the end of school, it is less likely that the exact timing of a transition into temporary employment is known much in advance. By definition, these workers are still unemployed in the third month after the end of schooling. For this group it is unlikely that they have accepted a job offer during schooling time, since these jobs would typically start during the first three months after the end of schooling. ${ }^{21}$ For the school-leavers in this sample it is consequently unlikely that anticipation effects play a noteworthy role.

Moreover, in the case of multivariate mixed proportional hazard models, we have to include at least two continuous explanatory variables that comprise sufficient variation, that affect the competing transition rates in different ways and that are not collinear. In the present paper we include several continuous explanatory variables: the regional unemployment rate, the subjective impression that the pollster has from the school-leaver and the age of the worker. Arguments in the literature on the identification of MMPH models suggest that these variables are useful for identification. In the case of independent mixed proportional hazard models as applied for the final results, continuous variables

\footnotetext{
${ }^{20}$ In the absence of repeated observation of the same transition for one individual, this type of assumption is required for the identification of the parameters that are associated to the observed characteristics in a multivariate mixed proportional hazard (MMPH)-model (Abbring, 2006).

${ }^{21}$ In Belgium, like in most European countries, it is not uncommon to have a short spell of inactivity or unemployment between the end of schooling and the start of the first employment, even for the case where the workers have already accepted a job offer during their schooling time.
} 
are not required for identification; see van den Berg (2001). To summarise, we think it is plausible to assume that the empirical model is identified for the sample of unemployed school-leavers.

\section{Specification of the likelihood-function}

In our empirical model we allow for three different labour market states: unemployment $u$, temporary employment $t$ and permanent employment $\mathrm{p}$. The model is of the mixed proportional hazard (MPH) type (see also van den Berg 2001). The equations for the different transition rates are estimated simultaneously by means of maximum likelihood. In this model, the observed explanatory variables $X$ and the unobserved characteristics $V$ shift the baseline hazard function $\lambda(t)$ proportionally. The transition rates out of unemployment can be written as: $\theta_{\mathrm{uq}}\left(\mathrm{t} \mid \mathrm{x}, \mathrm{V}_{\mathrm{q}}\right)=\lambda_{\mathrm{uq}}(\mathrm{t}) \cdot \exp \left(\mathrm{x}^{\prime} \beta_{\mathrm{uq}}+\mathrm{V}_{\mathrm{q}}\right)$, for $q \in\{t, p\}$. The transition rate from temporary employment to permanent employment as: $\theta_{\mathrm{tp}}\left(\mathrm{t} \mathrm{t}_{\mathrm{ut}} \mathrm{x}, \mathrm{V}_{\mathrm{p}}\right)=\lambda_{\mathrm{tp}}(\mathrm{t}) \cdot \exp \left(\mathrm{x}^{\prime} \beta_{\mathrm{tp}}+\mathrm{V}_{\mathrm{p}}\right)$.

We specify a flexible piecewise constant baseline hazards $\lambda(t)=\exp \left(\alpha_{\mathrm{lm}, \mathrm{k}}\right)$ where $\mathrm{k}$ indicates the month in origin state $\mathrm{I}$ and $\mathrm{m}$ is the destination state. We impose the following normalisation: $\alpha_{\mathrm{up}, 1}=\alpha_{\mathrm{ut}, 1}=\alpha_{\mathrm{tp}, 1}=1$. For details on the derivation of the individual likelihood contributions we refer to appendix 3.

The survival rate can be expressed as a function of the transition rate: $S_{q}(t)=\exp \left(-\int_{0}^{t} \theta_{q}(\tau \mid \cdot) d \tau\right)$ and their multivariate equivalent, respectively. Using $S_{u}\left(t_{k}\right)$ to note the survival rate at the end of the $\mathrm{k}$-th period in unemployment and $\mathrm{S}_{\mathrm{t}}\left(\mathrm{t}_{\mathrm{l}}\right)$ for the survival rate at the end of the I-th period after the transition to temporary employment, we can write the individual likelihood contribution for the grouped duration model as:

$$
\begin{aligned}
& \mathrm{I}_{\mathrm{m}}=\left\{\frac{\left[\theta_{\mathrm{ut}}\left(\mathrm{t}_{\mathrm{k}} \mid \cdot\right)^{\left(\mathrm{p}_{\mathrm{ut}}\right)}\right] \cdot\left[\theta_{\mathrm{up}}\left(\mathrm{t}_{\mathrm{k}} \mid \cdot\right)^{\left(1-\mathrm{putu}_{\mathrm{ut}}\right)}\right]}{\sum_{\mathrm{q} \in\{\mathrm{t}, \mathrm{p}\}} \theta_{\mathrm{uq}}\left(\mathrm{t}_{\mathrm{k}} \mid \cdot\right)}\left[\mathrm{S}_{\mathrm{u}}\left(\mathrm{t}_{\mathrm{k}-1} \mid \cdot\right)-\mathrm{S}_{\mathrm{u}}\left(\mathrm{t}_{\mathrm{k}} \mid \cdot\right)\right]\right\}^{\left(1-\mathrm{c}_{\mathrm{u}}\right)} \times\left[\mathrm{S}_{\mathrm{t}}\left(\mathrm{t}_{\mathrm{l}-1} \mid \cdot\right)-\mathrm{S}_{\mathrm{t}}\left(\mathrm{t}_{1} \mid \cdot\right)\right]^{\left(1-\mathrm{c}_{\mathrm{t}}\right) \cdot \text { put }_{\mathrm{ut}}} \\
& \times\left[\mathrm{S}_{\mathrm{u}}\left(\mathrm{t}_{\mathrm{k}} \mid \cdot\right)\right]^{\mathrm{c}_{u}} \times\left[\mathrm{S}_{\mathrm{t}}\left(\mathrm{t}_{1} \mid \cdot\right)\right]^{\left(1-\mathrm{c}_{u}\right) \cdot \mathrm{c}_{t} \cdot \mathrm{put}_{\mathrm{ut}}}
\end{aligned}
$$

Equation 1 represents all possible trajectories the individual can have in our model. For notational simplicity we do not explicitly write that all components used in equation 1 are conditional on a set of explanatory variables. Censoring in the respective states (unemployment and temporary employment) is indicated by $c_{u}$ and $c_{t}$. A transition to temporary employment is indicated by $p_{u t}$.

For the estimation of the model we proceed in two steps. In a first step we estimate a mixed proportional hazard model for each possible transition, independently. We suppose that the unobserved component $v$ follows a discrete distribution with a fixed number of mass points (Heckman and Singer, 1984). The locations of the discrete mass points as well as the associated probability are estimated simultaneously with the other parameters of the model. It is known from the literature that the choice of the number of mass points can be a cause of misspecification. In order to 
determine the correct number of mass points we apply penalized maximum likelihood, as suggested by the literature; see Baker and Melino (2000) and Gaure et al. (2007). More precisely, we use the Akaike information criterion: $\log L$ - (Number of parameters).

In a second step we specify the unobserved heterogeneity terms by a multivariate discrete distribution. Van den Berg (2001) argues that, in the case of multivariate mixed proportional hazard models, discrete distributions provide flexibility while limiting the computational costs of the estimation. We suppose that the unobserved component, $v_{q}$ with $q \in\{t, p\}$, can take $n$ values $\mathrm{v}_{\mathrm{q} 1}, \mathrm{v}_{\mathrm{q} 2}, \ldots, \mathrm{v}_{\mathrm{qn}}$ for each possible destination state $\mathrm{q}$.

The resulting individual likelihood contribution can then be written as:

$I_{m}=\sum_{a=1}^{n} \sum_{b=1}^{n} P_{a b} \cdot I_{m}\left(v_{t a}, v_{p b}\right)$, where $P_{a b}$ is the associated probability to each combination of these values. The probabilities are specified as a multinomial logit.

Details on the specification of the unobserved heterogeneity can be found in Appendix 4 . In the given framework, no selection in unobserved characteristics is equivalent to independence between the unobserved heterogeneity terms for the two possible transition rates (temporary employment and permanent employment). Finally, the lack of unobserved heterogeneity for at least one of the two destination states would indicate the absence of relevant selection in unobserved characteristics, since with a degenerated distribution in one transition any correlation between the unobserved characteristics of the transitions are ruled out. In this case, either unobserved heterogeneity is not important for the selection into temporary employment or unobserved heterogeneity is not important to explain the duration of interest (the duration until a transition into permanent employment). In both cases selection in unobserved characteristics would not be relevant for our evaluation.

\section{Results}

\section{Time dependence}

Figure 2 shows the shape of the piecewise constant baseline hazards for the three possible transitions. The baseline hazard is informative on the time dependency of the transition rates. All the lines in Figure 2 have been computed for the reference individual. In order to find a parsimonious specification we started of with a flexible baseline hazard where we allowed for a different value for each month. In a second step we imposed parameter restrictions for periods that follow each other and whose parameters have not been significantly different from each other. ${ }^{22}$

\footnotetext{
${ }^{22}$ We tested the validity of the imposed restrictions by means of a likelihood ratio test.
} 
In the short run, we see negative duration dependence for the transition out of unemployment (transition to temporary employment and to permanent employment). In the long run there seems to be no duration dependence and the transition rates are very low, compared to the start of the spell. The transition from temporary employment to permanent employment has two small peaks at 6 and 12 months. One interpretation for this pattern is that temporary employment contracts are often for duration of 6 or 12 months. Guëll and Petrongolo (2007) argue that the timing of the transition from temporary to permanent employment can be suggestive of alternative uses of temporary employment. In their baseline hazard rates for Spain, they found spikes around durations of one and three years. They put forward that the first one suggests the use of temporary employment as a screening device. The latter could be explained by the legal maximum duration of temporary employment. Different form Spain, in Flanders there is no strictly defined maximum duration for temporary employment. In our results there are only early spikes, suggesting the use of temporary employment as a screening device in some cases.

Table 2 provides some insights in whether the transition from temporary to permanent employment is with the same or another employer. For $35 \%$ the transition from temporary to a permanent contract is with the same employer, suggesting that employers use the temporary contract as a screening device since especially for school-leavers the productivity of the worker is difficult to assess. On the other hand $65 \%$ of unemployed school-leavers starting in a temporary job obtain a permanent contract with another employer. This fits well with the idea that temporary employment acts as a signal for employers.

Table 2: Incidence of a change of the employer, when entering permanent employment after temporary employment. (in \%)

\begin{tabular}{l|c} 
Same employer as in temporary employment & $35.4 \%$ \\
\hline Different employer & $64.6 \%$
\end{tabular}

\section{No selection in unobserved characteristics}

Our estimates indicate that there is no selection in unobserved characteristics. As described in the previous section we started with the estimation of independent mixed proportional hazard models for each transition. Already in this first step, when we go from one point of support (no unobserved heterogeneity) to a model with two points of support for the unobserved heterogeneity, the additional second mass point for the transition to temporary employment is rejected on the basis of the Akaike information criterion (AIC). This result is an indicator for the absence of unobserved heterogeneity in this transition. ${ }^{23}$ To be sure that this is not due to numerical problems we tested different sets of,

\footnotetext{
${ }^{23}$ In a simulation study Gaure et al. (2007) show that the AIC-criterion performs well to find the best specification for the unobserved heterogeneity distribution. Alternative criteria as the Bayesian information criterion (BIC) or the Hannan-Quinn information Criterion (HQIC) have a stronger penalty for additional parameters when the
} 
sometimes extreme, starting values. However, the model always converged to the same parameters, independently of the starting values. In order to check the sensitivity of the AIC we also re-estimated the model but deliberately left out a significant explanatory variable. In this case, AIC suggests a specification with unobserved heterogeneity for the transition into temporary employment.

The outcome of the specification test is different for the transitions to permanent employment, where we find support for a specification of unobserved heterogeneity with two mass points. Since there is only unobserved heterogeneity for one of the possible destinations, selection in unobserved characteristics is ruled out.

The suggested conditional independence between durations is an important result. In order to test the robustness of this result, we also estimate a multivariate mixed proportional hazard model with dependent risks and applied the specification test. Again, the dependent specification has to be rejected against a model with a degenerated distribution for the unobserved characteristics in the transition into temporary employment, on the basis of the Akaike Information Criterion.

The reason for the lack of support for a model with dependent unobserved heterogeneity is probably the rich dataset. Variables like driving license, club membership, welfare typology and pollster's impression might capture otherwise unobserved characteristics well. ${ }^{24}$

In the following all reported results are based on the model where the two possible values for the transition to temporary employment $\left(\mathrm{v}_{\mathrm{t} 1}\right.$ and $\left.\mathrm{v}_{\mathrm{t} 2}\right)$ are restricted to be equal.

\section{Effect of covariates}

Since the focus of this paper is on the effect of temporary employment, the effect of the explanatory variables is not our main concern. The main purpose of the covariates is to control for selective participation within the given framework. Nevertheless it would be worrying if the covariates would have effects on the transition rate that are beyond plausibility. Therefore, we provide only a brief summary of the main results. Appendix 5 provides the details for all covariates and transitions.

Higher education and apprenticeship experience increase the probability of leaving unemployment. 'Residential area' also influences both transition rates out of unemployment but in an opposite way. It has a negative effect for the transition to temporary employment, but a positive effect on the transition to permanent employment. A Belgian nationality, student work and living in a traditional rural area with recent urbanisation increase the transition from unemployment to temporary employment. A higher unemployment rate reduces the probability of a transition from unemployment to permanent employment, whereas club membership increases this probability. "Having a driving license" increase all transition probabilities significantly. Female respondents have lower transition rates to permanent employment (both out of unemployment and out of temporary employment). A more positive pollster's impression of the respondent has an upwards effect on the transition from temporary to permanent employment. In summary, the vast majority of the estimates for the explanatory variables are consistent with our expectations.

number of observations exceeds 15 . When an additional mass point is rejected on the basis of AIC it would consequently also be rejected by BIC and HQIC.

${ }^{24}$ This result suggests that one could also apply a matching approach. 


\section{Simulation of time-varying effects}

To get insights into the dynamics of the effects and into what the estimates actually mean, we perform simulation exercises. The general idea is to use the estimates of our model to simulate durations to permanent employment for the case of taking a temporary employment and for the counterfactual case of staying unemployed. For details on the simulation procedure we refer to Appendix 6 .

In a first step we check if our model simulation is able to reproduce the observed outcomes. Figure 3 shows the fraction of individuals that had already a transition into permanent employment $t$ months after the moment they entered temporary employment. The black line shows the fraction that is observed in the data, the gray line shows the same fraction, but obtained by the means of simulation. In order to obtain Monte-Carlo type confidence bands, we repeated the simulation exercise 400 times. The gray line represents the median value of the simulations and its confidence intervals. It is clear from Figure 3 that the simulated outcomes are close to the observed ones. Notice also that the observed fractions are never outside the $95 \%$ bounds of our simulations. Overall we conclude that the simulation is able to reproduce the observed outcomes rather well.

Since our research question is whether temporary employment helps school-leavers in their transition to permanent employment we want to know what would have happened in the hypothetical case where the school-leavers did not participate in temporary employment but instead remained in unemployment, searching for a direct transition into permanent employment. Therefore, we add the simulation for the hypothetical case of staying unemployed (and not taking temporary employment) to Figure 4. This figure thus presents the simulated fractions (of individuals who had already a transition to permanent employment after $t$ months) for unemployed school-leavers who participate in temporary employment as well as their counterfactual outcome for a situation without a transition into temporary employment.

In the short run the fraction of individuals in permanent employment after $\mathrm{t}$ months is lower, for the case of participation in temporary employment, than for the case in which they did not participate in temporary employment. In the long run, however, the opposite is true. The fraction of individuals in permanent employment after $t$ months is higher for school-leavers who have a transition into temporary employment than for the counterfactual situation without this transition.

\section{Stepping stone effect}

Figure 5 offers a comprehensible view of the stepping stone effect of temporary employment (i.e. the simulated individual difference caused by temporary employment) for unemployed school-leavers. Where Figure 4 presents the medians for the simulation (of both cases: participation in temporary employment or not), Figure 5 presents the median of the differences. For each draw of the data we computed the difference in both fractions. The results show a stepping stone effect of temporary 
employment. There is a negative effect of temporary employment during the first months, but from 21 months on workers in temporary employment perform better compared to the hypothetical situation where they stayed unemployed and looked for permanent employment directly.

A negative effect during the first month can be explained by the fact that workers who accept a temporary job are initially strongly attached to that job, for example because of contractual reasons. In addition to the contractual reasons the negative effect during the first months could be due to the limited time temporary workers might have to devote on job search (compared with unemployed school-leavers).

In the long run we find a positive effect of temporary employment for unemployed school-leavers. In our analysis we only considered unemployed school-leavers (and not unemployed people in general), as we want to estimate the causal effect of temporary employment for school-leavers who were actively looking for a job. If we compare our sample with all school-leavers, descriptive statistics suggests that our sample contains more low educated school-leavers, more school-leavers with a non-Belgian grandmother and less with club membership (reflecting a smaller social network). ${ }^{25}$ We conclude that temporary employment is a stepping stone for unemployed school-leavers, a group that has been put into context with high risk for unemployment in the literature. ${ }^{26}$

\section{What happens after the transition to permanent employment?}

We consider the transition to a permanent job as the final labour market state in our model. In the introduction we already presented research results indicating that people prefer a permanent job. A natural question would be to ask if permanent employment after a temporary employment experience is stable. The following descriptive statistics show that the first permanent employment spell is comparable, for the case of a preceding temporary employment or preceding unemployment. Table 3 shows the labour market state 3 months after the transition to permanent employment. We compare respondents who had a direct transition to permanent employment with those who had a transition to permanent employment after a temporary job. This table indicates that 3 months after the start of the permanent job $95 \%$ of the young people are still in permanent employment. We observe virtually no differences between both groups indicating that those who had a temporary first job and obtain a permanent one afterwards indeed succeeded to obtain a comparable employment. After one year still $78 \%$ are in permanent employment. However, since our database contains school-leavers and only covers a limited period on the labour market, the percentage of respondents censored before 12 months is higher (7\%). ${ }^{27}$

Table 3: Labour market status three months after the transition to permanent employment (in \%)

\footnotetext{
${ }^{25} 12.3 \%$ with a grandmother of non Belgian nationality versus $10.2 \% ; 14.9 \%$ of lower educated versus $11.6 \%$; $52.8 \%$ club membership versus $58.0 \%$.

${ }^{26}$ See for example Bradley and Taylor (1991), Bratberg and Nilsen (2000), Nielsen et al. (2003) and Vanoverberghe et al. (2008).

${ }^{27}$ These statistics are available from the authors on request.
} 


\begin{tabular}{|c|c|c|}
\hline \multirow[t]{2}{*}{ Situation 3 months later } & \multicolumn{2}{|c|}{ Respondents who had a transition from } \\
\hline & $\begin{array}{l}\text { Unemployment to } \\
\text { permanent employment }\end{array}$ & $\begin{array}{l}\text { Temporary employment to } \\
\text { permanent employment }\end{array}$ \\
\hline Permanent employment & $94,7 \%$ & $95,3 \%$ \\
\hline Not working & $3,1 \%$ & $2,2 \%$ \\
\hline Temporary employment & $1,4 \%$ & $1,0 \%$ \\
\hline \multirow[t]{2}{*}{ Censored before 3 months } & $0,7 \%$ & $1,5 \%$ \\
\hline & $100 \%$ & $100 \%$ \\
\hline
\end{tabular}

\section{Conclusion}

In this paper we investigate whether temporary employment acts as a stepping stone for unemployed school-leavers. We compare the duration between the start of temporary employment and a transition to permanent employment to the counterfactual duration until permanent employment in the absence of temporary employment. Our contribution to the literature is twofold. We estimate the causal effect of temporary employment controlling for possible selection in observed and unobserved characteristics. In addition, we investigate the stepping stone question for unemployed schoolleavers as unemployment and temporary employment are much higher among these younger people.

Our estimation results indicate that there is no selection in unobserved characteristics. We argue that this is due to our exceptionally rich database containing variables, which are often not observed (like the pollster's impression, club membership and driving license). Simulations are used to investigate the causal effect of temporary employment on the transition to permanent employment for unemployed school-leavers. We observe a time varying effect. Unemployed school-leavers who accept a temporary job have a low transition rate into permanent employment at the start of the temporary employment spell, which results in a lower fraction of those obtaining a permanent contract in the short run (compared with the hypothetical situation where these individuals remained unemployed). In the long run (from 21 months onwards) participants in temporary employment do better than the counterfactual situation in which these school-leavers remained unemployed during their search for a permanent job. We thus find a stepping stone effect for unemployed schoolleavers. Additional descriptive statistics indicate that the first permanent employment is as persistent after temporary employment than after a direct transition from unemployment. 


\section{Appendix 1: Figures}

Figure 1: Transitions in the empirical model

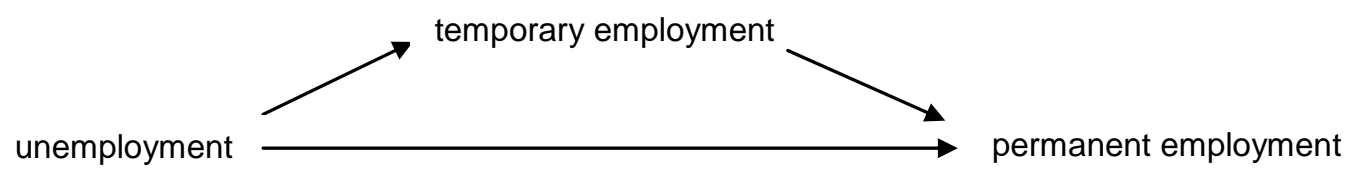

Figure 2: Baseline hazards

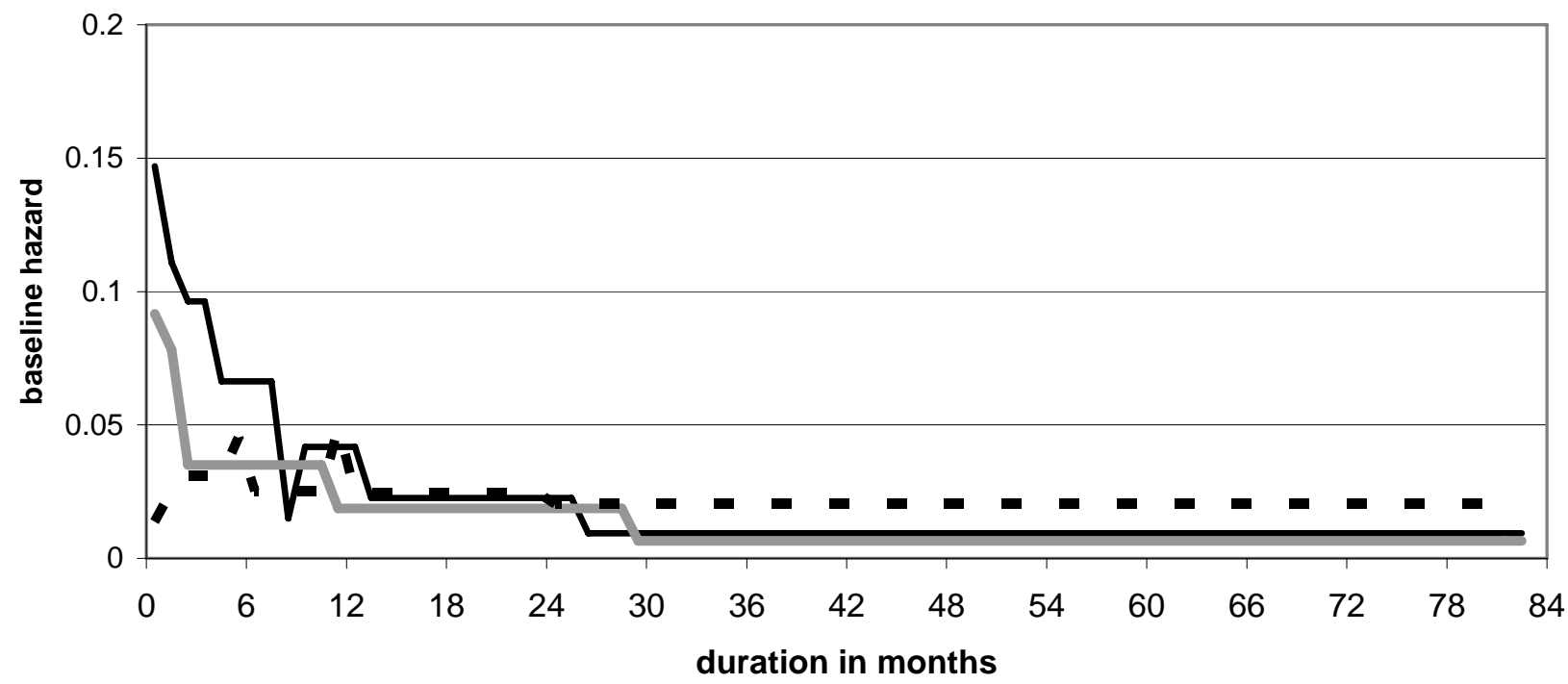

Unemployment to temporary Unemployment to permanent $\mathbf{a}$ Temporary to permanent

Note: starting point is always the start of a spell in a certain state. For the transitions from unemployment to temporary and permanent employment this is the third month after leaving school.

For the transition from temporary to permanent employment this is the start of the temporary employment spell. 
Figure 3: Simulation of the transition into permanent employment versus real data

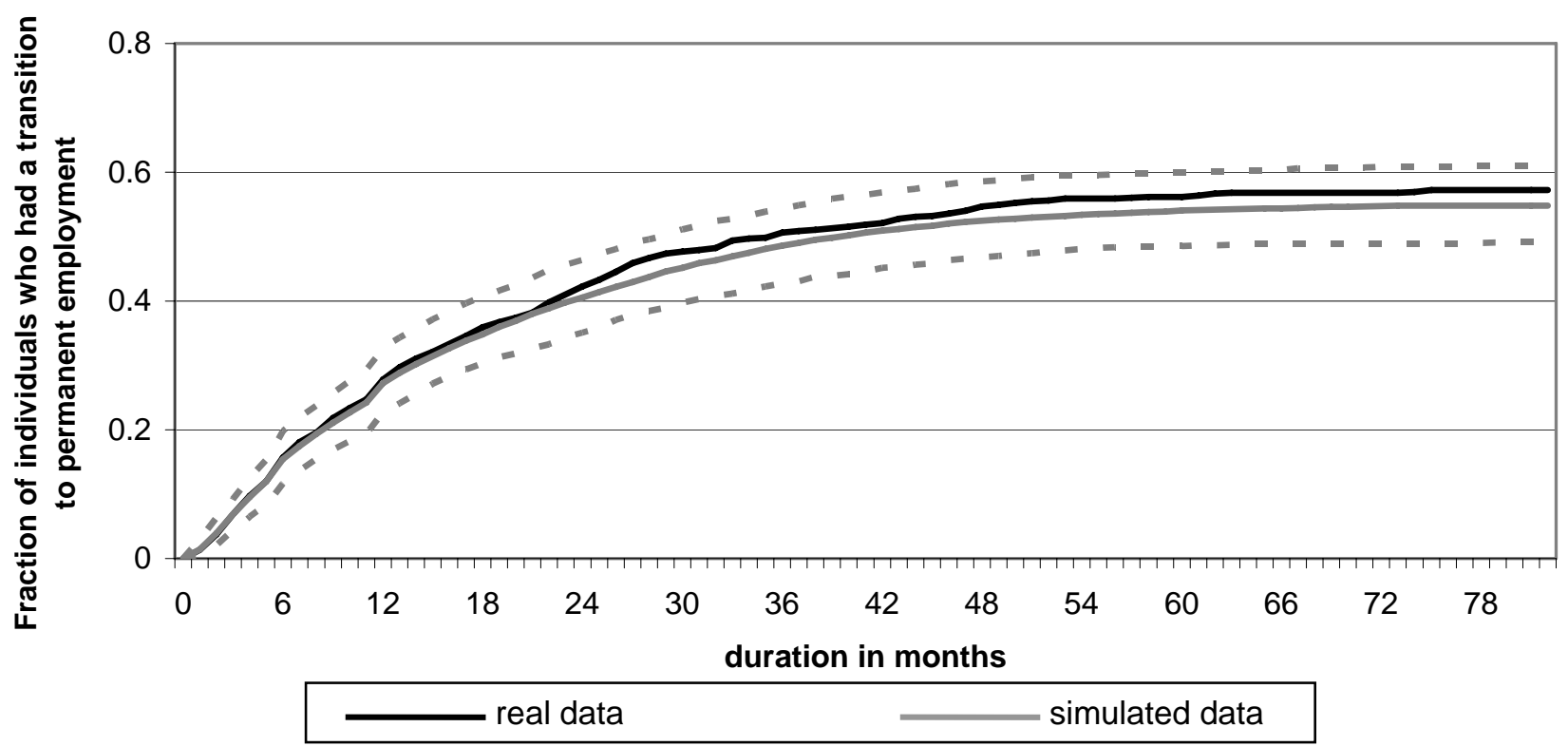

Note: starting point is the month of a transition into temporary employment spell $95 \%$ of the simulations results are within the confidence bounds 
Figure 4: Simulation of the transition into permanent employment with and without temporary employment

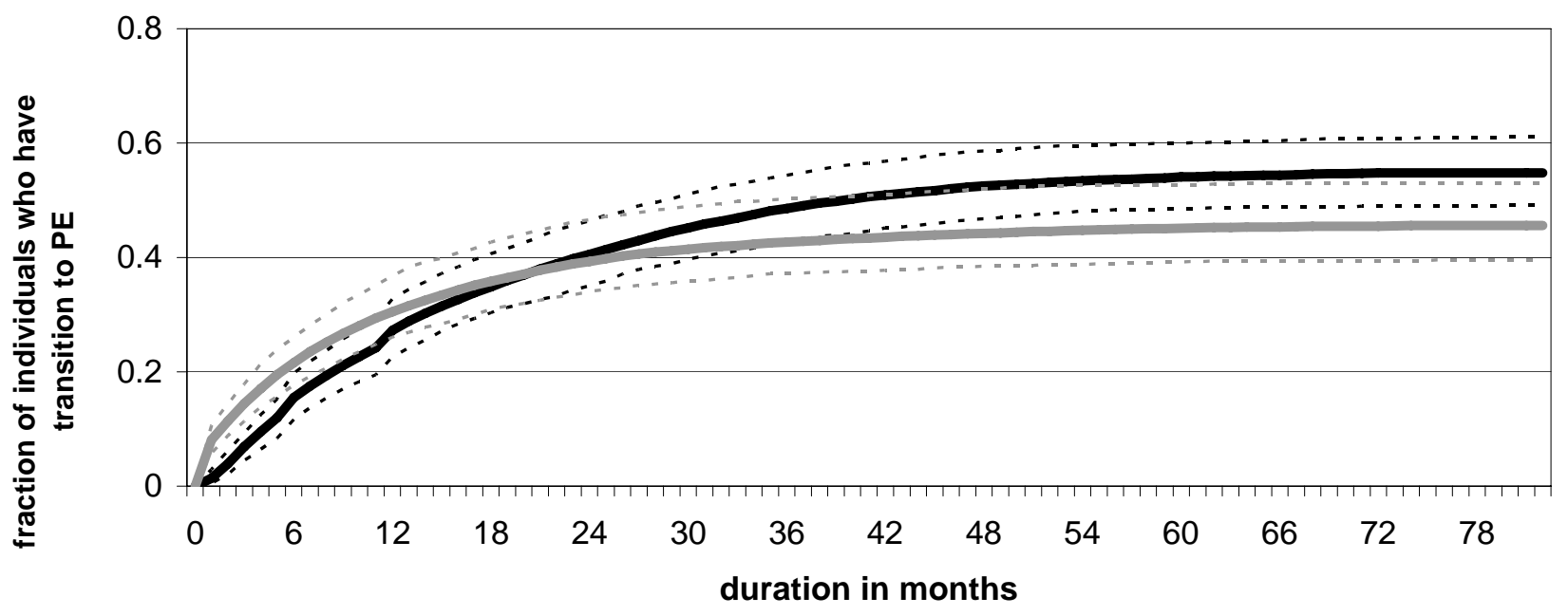

with TE without TE

Note: starting point is the month of a transition into temporary employment (TE) spell $95 \%$ of the simulations results are within the confidence bounds

Figure 5: Stepping stone effect: difference between the fractions caused by a transition into temporary employment

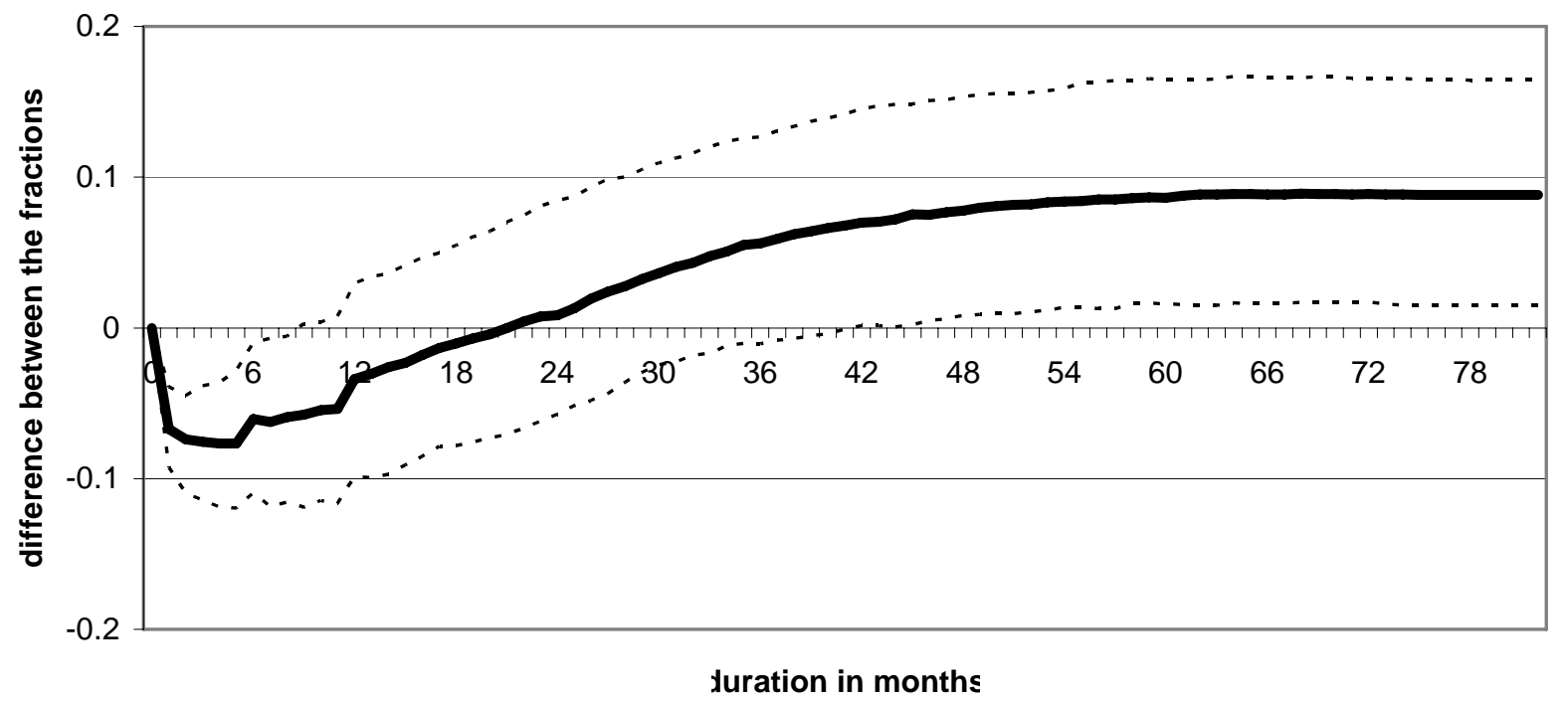

Note: starting point is the month of a transition into temporary employment spell $95 \%$ of the simulated differences are within the confidence bounds 


\section{Appendix 2: Descriptive statistics of explanatory variables}

\begin{tabular}{|c|c|c|c|}
\hline Variables & All & \begin{tabular}{|} 
Transition to PE \\
(without TE)
\end{tabular} & $\begin{array}{l}\text { Transition to } \\
\text { TE }\end{array}$ \\
\hline Number of observations & 1542 & 451 & 741 \\
\hline \multicolumn{4}{|l|}{ Time independent variables } \\
\hline Women & $53.6 \%$ & $46.1 \%$ & $59.8 \%$ \\
\hline Age in months & 253.88 (26.95) & $252.33(26.59)$ & $252.61(26.01)$ \\
\hline Respondent Belgian & $97.0 \%$ & $98.2 \%$ & $97.8 \%$ \\
\hline Respondent not Belgian & $3.0 \%$ & $1.8 \%$ & $2.2 \%$ \\
\hline Number of brothers and sisters & $1.78(1.51)$ & $1.76(1.49)$ & $1.72(1.48)$ \\
\hline Mother primary or lower secondary education & $35.9 \%$ & $33.7 \%$ & $37.0 \%$ \\
\hline Mother higher secondary education & $29.8 \%$ & $29.5 \%$ & $32.0 \%$ \\
\hline Mother tertiary education & $21.7 \%$ & $25.1 \%$ & $28.4 \%$ \\
\hline Mother unknown education & $12.6 \%$ & $11.8 \%$ & $12.7 \%$ \\
\hline Grandmother of respondent Belgian & $87.7 \%$ & $91.1 \%$ & $87.3 \%$ \\
\hline Grandmother of respondent not Belgian & $12.3 \%$ & $8.9 \%$ & $12.7 \%$ \\
\hline Respondent primary education & $5.6 \%$ & $5.3 \%$ & $5.4 \%$ \\
\hline Respondent lower secondary education & $9.3 \%$ & $9.5 \%$ & $9.0 \%$ \\
\hline Respondent higher secondary education & $47.0 \%$ & $49.9 \%$ & $47.0 \%$ \\
\hline Respondent lower tertiary education & $19.2 \%$ & $17.3 \%$ & $21.6 \%$ \\
\hline Respondent higher tertiary education & $18.9 \%$ & $18.0 \%$ & $17.0 \%$ \\
\hline Any apprenticeships during education & $60.6 \%$ & $63.4 \%$ & $63.6 \%$ \\
\hline Any student work during education & $36.3 \%$ & $39.0 \%$ & $40.2 \%$ \\
\hline $\begin{array}{l}\text { End education in vocational type (part time learning part time } \\
\text { work) }\end{array}$ & $6.9 \%$ & $6.9 \%$ & $6.5 \%$ \\
\hline $\begin{array}{l}\text { Member of any kind of club (youth movement, sports club, } \\
\text { political movement) }\end{array}$ & $52.8 \%$ & $56.1 \%$ & $49.5 \%$ \\
\hline $\begin{array}{l}\text { Pollsters impression of the respondent (only based on: calm, } \\
\text { friendly and open) }\end{array}$ & $0.038(0.96)$ & $-0.016(0.99)$ & $-0.052(0.97)$ \\
\hline \multicolumn{4}{|l|}{ Welfare typology (based on place of residence at 23) } \\
\hline Residential areas & $11.0 \%$ & $15.1 \%$ & $7.8 \%$ \\
\hline Urban living with average welfare & $23.8 \%$ & $25.1 \%$ & $20.6 \%$ \\
\hline Older industrial and working-class residential areas & $28.3 \%$ & $26.2 \%$ & $29.1 \%$ \\
\hline Modern urbanised areas & $25.2 \%$ & $22.1 \%$ & $27.5 \%$ \\
\hline Traditional rural areas with recent urbanisation'. & $11.7 \%$ & $11.5 \%$ & $14.8 \%$ \\
\hline \multicolumn{4}{|l|}{ Time dependent variables } \\
\hline Financial independent of parents at start of $U$ & $9.1 \%$ & $6.2 \%$ & $9.9 \%$ \\
\hline Living together at start of $U$ & $5.8 \%$ & $4.9 \%$ & $6.1 \%$ \\
\hline Number of children at start of $U$ & $0.018(0.16)$ & $0.016(0.14)$ & $0.014(0.15)$ \\
\hline Driving license at start of $U$ & $44.3 \%$ & $46.1 \%$ & $43.3 \%$ \\
\hline Unemployment rate at start of $U$ & $10.14(3.40)$ & $9.9(3.36)$ & $10.24(3.34)$ \\
\hline $\begin{array}{l}\text { Financial independent of parents at start of TE } \\
\text { Living together at start of TE } \\
\text { Number of children at start of TE }\end{array}$ & & & $\begin{array}{c}20.6 \% \\
10.0 \% \\
0.041(0.25)\end{array}$ \\
\hline
\end{tabular}


Note:

- The number of respondents with a transition to permanent employment -PE- (451) and those with a transition to temporary employment -TE- (741) together with the 349 censored individuals (not yet a transition to temporary employment or permanent employment at the moment of the last interview) sum up to the first sample size (1542)

- " "start of U" refers to the start of the unemployment spell, "start of TE" refers to the start of the temporary employment

- Significant (5\% level) differences are indicated in Bold Italic.

\section{Appendix 3: The likelihood function of the duration model}

First we consider the state of unemployment. For this state we define two random durations $\mathrm{T}_{\text {uq }}$ : the random duration from unemployment to state $q$ (with $q \in\{t, p\}$ ). Similarly for the temporary employment state we define $T_{t p}$ : the random duration in temporary employment until permanent employment

We assume that all individual differences in the joint distribution $T=\left(T_{u t}, T_{u p}, T_{t p}\right)$ can be characterised by explanatory variables $\mathrm{X}, \mathrm{V}$ where $\mathrm{X}$ is observed and $\mathrm{V}$ is not.

This joint distribution $T \mid X, V$ can be expressed in terms of the distributions $\left(T_{u t} \mid X=x, V\right)$, $\left(T_{\text {up }} \mid \mathrm{X}=\mathrm{X}, \mathrm{V}\right)$

and $\left(T_{t p} \mid T_{u p}=t_{u p}, X=x, V\right)$. The latter distributions are characterised by their transition rates: $\theta_{\mathrm{ut}}(\mathrm{t} \mid \mathrm{x}, \mathrm{V}), \theta_{\mathrm{up}}(\mathrm{t} \mid \mathrm{x}, \mathrm{V})$ and $\theta_{\mathrm{tp}}\left(\mathrm{t} \mid \mathrm{t}_{\mathrm{ut}}, \mathrm{x}, \mathrm{V}\right)$

Let $V=\left(V_{t}, V_{p}\right)$ be $a(2 \times 1)$-vector of unobserved (destination specific) covariates, implying that: $\theta_{\mathrm{ut}}(\mathrm{t} \mid \mathrm{x}, \mathrm{V})=\theta_{\mathrm{ut}}\left(\mathrm{t} \mid \mathrm{x}, \mathrm{V}_{\mathrm{t}}\right)$, $\theta_{\mathrm{up}}(\mathrm{t} \mid \mathrm{x}, \mathrm{V})=\theta_{\mathrm{up}}\left(\mathrm{t} \mid \mathrm{x}, \mathrm{V}_{\mathrm{p}}\right)$, $\theta_{\mathrm{tp}}\left(\mathrm{t} \mid \mathrm{t}_{\mathrm{ut}}, \mathrm{x}, \mathrm{V}\right)=\theta_{\mathrm{tp}}\left(\mathrm{t} \mid \mathrm{t}_{\mathrm{ut}}, \mathrm{x}, \mathrm{V}_{\mathrm{p}}\right)$.

\section{Individual contributions to the likelihood function}

Now, we consider the individual contributions to the likelihood function.

Consider an individual in the flow sample and consider the likelihood contribution. We can distinguish the following cases: 
1. right censored at unemployment duration $t_{k}$ :

$$
\begin{aligned}
\mathrm{I}_{1}(\mathrm{~V}) & =\mathrm{P}\left(\mathrm{T}_{\mathrm{ut}}>\mathrm{t}_{\mathrm{k}}, \mathrm{T}_{\text {up }}>\mathrm{t}_{\mathrm{k}} \mid \cdot\right) \\
& =\mathrm{S}_{\mathrm{u}}\left(\mathrm{t}_{\mathrm{k}} \mid \cdot\right)
\end{aligned}
$$

2. leaving first unemployment for temporary employment within $\left[\mathrm{t}_{\mathrm{k}-1}, \mathrm{t}_{\mathrm{k}}\right]$ and right censored during temporary employment after $t_{1}$ months:

$$
\begin{aligned}
\mathrm{I}_{2}(\mathrm{~V}) & =\mathrm{P}\left(\mathrm{t}_{\mathrm{k}-1}<\mathrm{T}_{\mathrm{ut}} \leq \mathrm{t}_{\mathrm{k}}, \mathrm{T}_{\mathrm{tp}}>\mathrm{t}_{\mathrm{l}} \mid \cdot\right) \\
& =\left\{\frac{\theta_{\mathrm{ut}}\left(\mathrm{t}_{\mathrm{k}}\right)}{\sum_{\mathrm{q} \in\{\mathrm{t}, \mathrm{p}\}} \theta_{\mathrm{uq}}\left(\mathrm{t}_{\mathrm{k}}\right)}\left[\mathrm{S}_{\mathrm{u}}\left(\mathrm{t}_{\mathrm{k}-1}\right)-\mathrm{S}_{\mathrm{u}}\left(\mathrm{t}_{\mathrm{k}}\right)\right]\right\} \mathrm{S}_{\mathrm{t}}\left(\mathrm{t}_{\mathrm{l}} \mid \cdot\right)
\end{aligned}
$$

3. leaving unemployment for temporary employment within $\left[t_{k-1}, t_{k}\right]$ and leaving for permanent employment within $\left[\mathrm{t}_{1-1}, \mathrm{t}_{1}\right]$.

$$
\begin{aligned}
\mathrm{I}_{3}(\mathrm{~V}) & =\mathrm{P}\left(\mathrm{t}_{\mathrm{k}-1}<\mathrm{T}_{\mathrm{ut}} \leq \mathrm{t}_{\mathrm{k}}, \mathrm{t}_{\mathrm{l}-1}<\mathrm{T}_{\mathrm{tp}} \leq \mathrm{t}_{\mathrm{l}}\right) \\
& =\left\{\frac{\theta_{\mathrm{ut}}\left(\mathrm{t}_{\mathrm{k}}\right)}{\sum_{\mathrm{q} \in\{\mathrm{t}, \mathrm{p}\}} \theta_{\mathrm{uq}}\left(\mathrm{t}_{\mathrm{k}}\right)}\left[\mathrm{S}_{\mathrm{u}}\left(\mathrm{t}_{\mathrm{k}-1}\right)-\mathrm{S}_{\mathrm{u}}\left(\mathrm{t}_{\mathrm{k}}\right)\right]\right\} \times\left[\mathrm{S}_{\mathrm{t}}\left(\mathrm{t}_{\mathrm{l}-1}\right)-\mathrm{S}_{\mathrm{t}}\left(\mathrm{t}_{\mathrm{l}}\right)\right]
\end{aligned}
$$

4. leaving first unemployment for permanent employment within $\left[\mathrm{t}_{\mathrm{k}-1}, \mathrm{t}_{\mathrm{k}}\right]$.

$$
\begin{aligned}
\mathrm{I}_{4}(\mathrm{~V}) & =\mathrm{P}\left(\mathrm{t}_{\mathrm{k}-1}<\mathrm{T}_{\mathrm{up}} \leq \mathrm{t}_{\mathrm{k}}, \mathrm{T}_{\mathrm{ut}}>\mathrm{t}_{\mathrm{k}} \mid \cdot\right) \\
& =\left\{\frac{\theta_{\mathrm{up}}\left(\mathrm{t}_{\mathrm{k}}\right)}{\sum_{\mathrm{q} \in\{\mathrm{t}, \mathrm{p}\}} \theta_{\mathrm{uq}}\left(\mathrm{t}_{\mathrm{k}}\right)}\left[\mathrm{S}_{\mathrm{u}}\left(\mathrm{t}_{\mathrm{k}-1}\right)-\mathrm{S}_{\mathrm{u}}\left(\mathrm{t}_{\mathrm{k}}\right)\right]\right\}
\end{aligned}
$$

\section{Appendix 4: Specification of the heterogeneity distribution}

Suppose that $\mathrm{V}_{\mathrm{q}}(\mathrm{q} \in\{\mathrm{t}, \mathrm{p}\})$ can take two values $\mathrm{v}_{\mathrm{q} 1}$ and $\mathrm{v}_{\mathrm{q} 2}$ for each possible destination state $\mathrm{q}$. In the case of independence between the unobserved heterogeneity terms for the two possible destinations (temporary employment and permanent employment) we estimate the probabilities for the two points of support independently by a binomial logit model:

$$
\mathrm{p}_{1 \mathrm{t}}=\frac{\exp \left(\lambda_{1 \mathrm{t}}\right)}{1+\exp \left(\lambda_{1 \mathrm{t}}\right)} \quad \mathrm{p}_{2 \mathrm{t}}=1-\mathrm{p}_{1 \mathrm{t}} \quad \text { and } \quad \mathrm{p}_{1 \mathrm{p}}=\frac{\exp \left(\lambda_{1 \mathrm{p}}\right)}{1+\exp \left(\lambda_{1 \mathrm{p}}\right)} \quad \mathrm{p}_{2 \mathrm{p}}=1-\mathrm{p}_{1 \mathrm{p}}
$$


Then the joint probabilities for the independent UH can be written as the product of these independent probabilities:

$P_{11}=P\left(V_{t}=v_{t 1}, V_{p}=v_{p 1}\right)=p_{1 t} \cdot p_{1 p}$

$P_{12}=P\left(V_{t}=v_{t 1}, V_{p}=v_{p 2}\right)=p_{1 t} \cdot p_{2 p}$

$P_{21}=P\left(V_{t}=v_{t 2}, V_{p}=v_{p 1}\right)=p_{2 t} \cdot p_{1 p}$

$P_{22}=P\left(V_{t}=v_{t 2}, V_{p}=v_{p 2}\right)=p_{2 t} \cdot p_{2 p}$

In the case of a model with multivariate dependent $\mathrm{UH}$ we have a joint heterogeneity distribution with 4 points of support and the following probabilities associated to these:

$P_{11}=P\left(V_{t}=v_{t 1}, V_{p}=v_{p 1}\right)=p_{1}$

$P_{12}=P\left(V_{t}=v_{t 1}, V_{p}=v_{p 2}\right)=p_{2}$

$P_{21}=P\left(V_{t}=v_{t 2}, V_{p}=v_{p 1}\right)=p_{3}$

$P_{22}=P\left(V_{t}=v_{t 2}, V_{p}=v_{p 2}\right)=p_{4}$

Or in a shortcut notation $P_{a b}=P\left(V_{t}=v_{t a}, V_{p}=v_{p b}\right)=p_{j}$ where each of the elements $a, b$ can take one of the values 1,2 (which results in $2^{2}$ different combinations), each unique combination is named by $p_{j}$ where $j=1, \ldots, 4$.

Again, the associated probabilities have been specified by a multinomial logit model:

$\mathrm{p}_{\mathrm{j}}=\frac{\exp \left(\lambda_{\mathrm{j}}\right)}{1+\sum_{\mathrm{i}=1}^{3} \exp \left(\lambda_{\mathrm{i}}\right)}$

for $\mathrm{j}=1,2,3$ and

$\mathrm{p}_{4}=1-\sum_{\mathrm{j}=1}^{3} \exp \left(\lambda_{\mathrm{j}}\right)=\frac{1}{1+\sum_{\mathrm{i}=1}^{3} \exp \left(\lambda_{\mathrm{i}}\right)}$ 


\section{Appendix 5: Estimation results}

\begin{tabular}{|c|c|c|c|c|}
\hline \multicolumn{5}{|c|}{ Trancition } \\
\hline \\
\hline \multirow[t]{29}{*}{ U-TE } & woman & 0.1075 & 0.0834 & 1.28897 \\
\hline & age (in months) & -0.0036 & 0.0028 & -1.2857 \\
\hline & not Belgian & -0.6876 & 0.2495 & -2.7559 \\
\hline & number siblings & -0.0534 & 0.0291 & -1.8351 \\
\hline & mother primary or lower secondary education (ref) & & & \\
\hline & mother higher secondary education & 0.1527 & 0.0959 & 1.59228 \\
\hline & mother tertiary education & -0.1733 & 0.1243 & -1.3942 \\
\hline & mother unknown education & -0.0444 & 0.1277 & -0.3477 \\
\hline & not Belgian grandmother & 0.1189 & 0.1342 & 0.88599 \\
\hline & primary education & -0.2386 & 0.2063 & -1.1566 \\
\hline & lower secondary education & -0.2868 & 0.1502 & -1.9095 \\
\hline & higher secondary education (ref) & & & \\
\hline & tertiary education & 0.683 & 0.1208 & 5.65397 \\
\hline & no apprenticeship & -0.2304 & 0.0863 & -2.6698 \\
\hline & no student work & -0.3944 & 0.1194 & -3.3032 \\
\hline & no vocational training & -0.2389 & 0.1719 & -1.3898 \\
\hline & not member club & -0.0824 & 0.0833 & -0.9892 \\
\hline & pollster's impression of respondent & -0.0521 & 0.0408 & -1.277 \\
\hline & residential areas & -0.3844 & 0.1578 & -2.436 \\
\hline & urban living with average welfare & -0.1748 & 0.1123 & -1.5565 \\
\hline & older industrial and working-class residential areas (ref) & & & \\
\hline & modern urbanised areas & 0.0268 & 0.1121 & 0.23907 \\
\hline & traditional rural areas with recent urbanisation'. & 0.2917 & 0.128 & 2.27891 \\
\hline & financial independent of parents & -0.0111 & 0.14 & -0.0793 \\
\hline & living together & -0.0432 & 0.1945 & -0.2221 \\
\hline & number children & -0.2164 & 0.2679 & -0.8078 \\
\hline & driving license & 0.2684 & 0.0933 & 2.87674 \\
\hline & regional unemployment rate & -0.0136 & 0.0186 & -0.7312 \\
\hline & cohort1976 & -0.2555 & 0.1241 & -2.0588 \\
\hline \multirow[t]{23}{*}{ U-PE } & woman & -0.4188 & 0.127 & -3.2976 \\
\hline & age (in months) & -0.0076 & 0.0041 & -1.8537 \\
\hline & not Belgian & -0.7749 & 0.4139 & -1.8722 \\
\hline & number siblings & 0.0176 & 0.0424 & 0.41509 \\
\hline & mother primary or lower secondary education (ref) & & & \\
\hline & mother higher secondary education & 0.0961 & 0.1559 & 0.61642 \\
\hline & mother tertiary education & 0.18 & 0.1703 & 1.05696 \\
\hline & mother unknown education & -0.163 & 0.1935 & -0.8424 \\
\hline & not Belgian grandmother & -0.4137 & 0.2192 & -1.8873 \\
\hline & primary education & -0.2601 & 0.2694 & -0.9655 \\
\hline & lower secondary education & -0.3065 & 0.2319 & -1.3217 \\
\hline & higher secondary education (ref) & & & \\
\hline & tertiary education & 0.4248 & 0.1836 & 2.31373 \\
\hline & no apprenticeship & -0.4029 & 0.1292 & -3.1184 \\
\hline & no student work & -0.1742 & 0.169 & -1.0308 \\
\hline & no vocational training & -0.3898 & 0.2526 & -1.5432 \\
\hline & not member club & -0.2706 & 0.1258 & -2.151 \\
\hline & pollster's impression of respondent & 0.0327 & 0.0612 & 0.53431 \\
\hline & residential areas & 0.4006 & 0.1934 & 2.07135 \\
\hline & urban living with average welfare & 0.136 & 0.1628 & 0.83538 \\
\hline & older industrial and working-class residential areas (ref) & & & \\
\hline & modern urbanised areas & -0.0065 & 0.1798 & -0.0362 \\
\hline & traditional rural areas with recent urbanisation'. & 0.0889 & 0.1985 & 0.44786 \\
\hline
\end{tabular}


financial independent of parents

living together

number children

driving license

regional unemployment rate

cohort1976

TE-PE
$-0.5001$

$-0.0278$

$-0.0186$

0.4401

$-0.0575$

$-0.1544$

$-0.6154$

$-0.0067$

$-0.2699$

$-0.0773$

number siblings

mother primary or lower secondary education (ref)

mother higher secondary education

mother tertiary education

mother unknown education

not Belgian grandmother

primary education

lower secondary education

higher secondary education (ref)

tertiary education

no apprenticeship

no student work

no vocational training

not member club

pollster's impression of respondent

residential areas

urban living with average welfare

older industrial and working-class residential areas (ref)

modern urbanised areas

traditional rural areas with recent urbanisation'.

financial independent of parents

living together

number children

driving license

regional unemployment rate

cohort1976

$\begin{array}{ccc}0.0279 & 0.164 & 0.17012 \\ -0.129 & 0.1981 & -0.6512 \\ -0.0629 & 0.2026 & -0.3105 \\ -0.3469 & 0.2594 & -1.3373 \\ -0.5075 & 0.3013 & -1.6844 \\ -0.2714 & 0.2699 & -1.0056 \\ & & \\ -0.1794 & 0.2183 & -0.8218 \\ 0.3336 & 0.1452 & 2.29752 \\ -0.1984 & 0.2133 & -0.9301 \\ 0.2462 & 0.2853 & 0.86295 \\ 0.073 & 0.1399 & 0.5218 \\ 0.1802 & 0.073 & 2.46849 \\ 0.5521 & 0.2669 & 2.06857 \\ 0.4774 & 0.1963 & 2.43199 \\ & & \\ 0.0786 & 0.1865 & 0.42145 \\ 0.3802 & 0.2115 & 1.79764 \\ 0.1828 & 0.1823 & 1.00274 \\ -0.2385 & 0.2513 & -0.9491 \\ -0.0404 & 0.4413 & -0.0915 \\ 0.3119 & 0.1489 & 2.09469 \\ -0.0393 & 0.0295 & -1.3322 \\ -0.0222 & 0.219 & -0.1014\end{array}$

$-0.2189$

$-0.2721$

$-0.5225$

$-1.9548$

$-0.8877$

$-1.3853$

$-2.0707$

0.123

$-1.7797$

month 4-5

month 10

month 11-14

month 15-27

month 28-84

\begin{tabular}{l|l} 
U-PE & month 3 \\
month 4-12 \\
month 13-30 \\
month 31-84
\end{tabular}

$\begin{array}{lll}-0.0244 & 0.1553 & -0.1571 \\ -0.5558 & 0.1482 & -3.7503\end{array}$

$\begin{array}{lll}-0.5558 & 0.1482 & -3.7503\end{array}$

$\begin{array}{lll}-0.6891 & 0.2225 & -3.0971\end{array}$

$\begin{array}{lll}-1.2636 & 0.3447 & -3.6658\end{array}$

$\begin{array}{lll}0.6223 & 0.4154 & 1.49807\end{array}$

$\begin{array}{lll}0.8814 & 0.3619 & 2.43548\end{array}$

$\begin{array}{lll}1.3331 & 0.3876 & 3.43937\end{array}$

$\begin{array}{lll}0.8445 & 0.3613 & 2.33739\end{array}$

$\begin{array}{lll}1.5818 & 0.4098 & 3.85993\end{array}$

$\begin{array}{lll}1.0227 & 0.3697 & 2.7663\end{array}$ 
const U-PE vp1

\section{Appendix 6: Simulation of the effect of temporary employment}

For the simulation we proceed like follows:

1. Make a random draw from estimated parameters for each individual. (Assuming that the parameters are distributed normally and have the mean equal to the parameter estimate and the standard deviation equal to the standard error of the parameters)

2. Using the parameter estimates and the characteristics of the individuals to compute the (random) transition rate for each individual and for each possible transition. We have performed an auxiliary estimation for the transition rates of censoring.

3. Given the transition rates, draw a random durations for all possible transitions.

4. The smallest durations for transitions are assumed to be realized.

5. The remaining random draws are used to obtain the duration for the counterfactual case of no transition to temporary employment.

6. Use the simulated data to compute the statistics (the fraction who had a transition to permanent employment) .

(7. Optional: Check if the model is able to reproduce the real data (e.g. see figure 3).)

(8. Optional: Contrast the simulated participation with the simulated counterfactual (e.g. see figure 4).)

9. Compute the differences: this is the effect of temporary employment on the fraction of people who had a transition to permanent employment (e.g. see figure 5). 


\section{Appendix 7: Bibliography}

Abbring J.H. and van den Berg G.J. (2003), The non-parametric identification of treatment effects in duration models, Econometrica, 71: 1491-1517

Baker, M. \& Melino, A. (2000), Duration dependence and nonparametric heterogeneity: a Monte Carlo study, Journal of Econometrics 96, 357-393

Becker G. (1964), Human Capital, Chicago, University of Chicago Press

Booth A. L., Francesconi M. en Frank J., 2002, Temporary jobs: stepping stones or dead ends, The Economic Journal, Vol. 112 (480), F189-F213

Blanchflower D. and Freeman R. (2000), The declining economic status of young workers in OECD countries, In Youth Employment and Joblessness in Advanced Countries, D. Blanchflower and R. Freeman (eds.), NBER Comparative Labor Markets Series, Chicago, University of Chicago Press, 19-55

Bradley S. and Taylor J. (1991), An empirical analysis of the unemployment duration of schoolleavers, Applied Economics, 24, 89-101

Bratberg E. and Nilsen $\varnothing$. (2000), Transitions from school to work and the early labour market experience, Oxford Bulletin of Economics and Statistics, 62, Special Issue, 909-929

D'Addio A.C. and Rosholm M. (2005), Exits from temporary jobs in Europe: a competing risks analysis, Labour Economics vol. 12 (4), 449-468

Declerck V., De Witte H. \& De Cuyper N. (2006), Motieven voor tijdelijk werk en uitzendarbeid, Over.Werk Tijdschrift van het Steunpunt WAV, 1-2/2006, 147-151

De Witte H., Vander Steene T., Dejonckheere J., Forrier A., Sels L. \& Van Hooteghem G. (2001), Contractueel flexibele werknemers: wie zijn ze en waarom doen ze het?; Cahier 6, HIVAKULeuven

European Commission (2006), Employment in Europe 2006

FOD Werkgelegenheid, Arbeid en Sociaal Overleg (2006), Verklarende nota 'Opeenvolgende arbeidsovereenkomsten voor bepaalde tijd', www.meta.fgov.be

Flinn C.J. and Heckman J.J. (1983), Are unemployment and out of the labor force behaviourally distinct labor states?, Journal of Labor Economics, vol.1, (1), 28-42

Forrier A. en Sels L., 2003, Temporary employment and employability: training opportunities and efforts of temporary and permanent employees in Belgium, Work, employment and society, Vol. 17(4), 641-666

Gagliarducci S., (2005), The dynamics of repeated temporary jobs, Labour Economics vol. 12 (4), 429-448

Gaure S., Røed K. \& Zhang T. (2007), Time and causality: A Monte Carlo assessment of the timingof-events approach, Journal of Econometrics 141, 1159-1195

Guest D.(2004), Flexible employment contracts, the psychological contract and employee outcomes: an analysisand review of the evidence, International Journal of Management Reviews, vol. 5/6 Issue 1, 1-19

Guell, M. \& Petrongolo B. (2007), How binding are legal limits? Transitions from temporary to permanent work in Spain, Labour Economics, vol. 14(2), 153-183 
Hagen T.(2003), Do fixed-term contracts increase the long term employment opportunities of the unemployed?, ZEW Discussion Paper 03

Heckman, J. \& Singer B. (1984), A method for minimizing the impact of distributional assumption in econometric models for duration data Econometrica 52, 271-320

Ichino A., Mealli F. \& Nannicini T. (2005), Temporary work agencies in Italy: a springboard toward permanent employment?, Giornale degli economisti e annali di economia, 118, 64(1), 1-27

Lancaster T. (1992), The econometric analysis of transition data, Cambridge University Press

Lindbeck A. and Snower D. (2002), The insider-outsider theory: a survey, IZA Discussion paper $\mathrm{n}^{\circ}$ 534

McGinnity F., Mertens A. en Gundert S.,2005, A bad start? Fixed term contracts and the transition from education to work in West Germany, European Sociological Review 21 (4), 359-374.

McGovern , Smeaton D. en Hill S., 2004, Bad jobs in Britain. Non standard employment and job quality, Work and Occupations, Vol. 31(2), 225-249.

Montgomery J. (1991), 'Social networks and labor-market outcomes: toward an economic analysis', American Economic Review, 81 (3), 1408-1418

OECD, 2002, Taking the measure of temporary employment, Employment Outlook, Paris, 127-187

OECD, 2004, Employment Outlook, Chapter 2 'Employment protection regulation and labour market performance'

Mortensen D., (1986), 'Job search and labor markets analysis', in: Handbook of Labor Economics, vol 2, pp. 849-919, North-Holland

Nielsen H., Rosholm M., Smith N. and Husted L. (2003), The school-to-work transition of $2^{\text {nd }}$ generation immigrants in Denmark, Journal of Population Economics, 16, 755-786

Nordström Skans O. (2004), Scarring effects of the first labour market experience: a sibling based analysis, IFAU Working Paper, 2004:14, 43p.

Piore M. (1970), Jobs and training in: Beer S. and Barringer R., eds, The state and the Poor, Cambridge , Mass, Whinthrop, 329 , pp. 53-83

Rees A. (1986), An essay on youth joblessness, Journal of Economic Literature vol. 24 (2), 613-628

Ryan (2001), The school-to-work Transition: a cross national perspective, Journal of Economic Literature vol. 39 (1), 34-92

Scherer S., 2004,"Stepping stones or traps? The consequences of labour market entry positions on further careers in West Germany, Great Britain and Italy", Work, employment and society, Vol. 18(2), 369-394

Sels L., Forrier A., De Witte H., Vander Steene T. and Van Hootegem G. (2002), Gelijk loon voor gelijk werk? Arbeidsvoorwaarden van vaste en tijdelijke werknemers, Tijdschrift voor arbeidsvraagstukken, 18(3), 196-209

SONAR (2000) Jongeren in transitie, De arbeidsmarkt in Vlaanderen, Jaarreeks 2000, deel 4 Leuven: Steunpunt WAV

Spence M. (1973), Job market signalling, Quarterly Journal of Economics, 87 (3), 355-374

Steijn B. en Need A.(2003), Loopbaaneffecten van flexibele arbeid, Tijdschrift voor Arbeidsvraagstukken, vol.19(2), 110-121 
Stiglitz J.E. (1975), The Theory of Screening, Education and the Distribution of Income, The American Economic Review, Vol. 65(3), 283-300

Tauban P. and Wachter M.L., Segmented Labor Markets, in: Handbook of Labor Economics volume II, ed. By AshenfelterO. And Layard R., 1986, p.1183-1217

van den Berg G.J (2001), Duration models: Specification, identification, and multiple durations. In Heckman J.J. and Leamer E., editors, Handbook of Econometrics, volume 5, chapter 55. North-Holland, Amsterdam

van den Berg G.J., Holm A. and van Ours J.C.(2002), Do stepping stone job exist? Early career paths in the medical profession, Journal of Population Economics, vol.15, 647-665

Vanoverberghe J., Verhaest D., Verhofstadt E. and Omey E., The transition from school to work in Flanders: a duration analysis, Journal of Education and Work, forthcoming

Verhaest D., Vanoverberghe J; and Omey E. (2006), How well do we measure skill acquisition and its determinants?, paper presented at the 12th workshop of the European Network of Transitions in Youth (2-4 September 2004), Nürnberg, revised version October 2006

Zijl M., van den Berg G. J. en Heyma A. (2004), Stepping - stones for the unemployed: the effect of temporary jobs on the duration until regular work, Discussion Paper 30, Stichting voor Economisch Onderzoek der Universiteit van Amsterdam

Zijl M. and van Leeuwen M (2005), Temporary jobs: intermediate positions or jumping boards, Discussion Paper 38, Stichting voor Economisch Onderzoek der Universiteit van Amsterdam 